Florida International University FIU Digital Commons

7-6-2016

\title{
Evaluating the Economic Impact of Recreational Charter Fishing in Florida Using Hedonic Price and Economic Impact Analysis
}

Mehrnoosh Asadi

DOI: $10.25148 /$ etd.FIDC000774

Follow this and additional works at: https://digitalcommons.fiu.edu/etd

Part of the Environmental Studies Commons

\section{Recommended Citation}

Asadi, Mehrnoosh, "Evaluating the Economic Impact of Recreational Charter Fishing in Florida Using Hedonic Price and Economic Impact Analysis" (2016). FIU Electronic Theses and Dissertations. 2547.

https://digitalcommons.fiu.edu/etd/2547 


\section{FLORIDA INTERNATIONAL UNIVERSITY \\ Miami, Florida}

EVALUATING THE ECONOMIC IMPACT OF RECREATIONAL

CHARTER FISHING IN FLORIDA USING

HEDONIC PRICE AND ECONOMIC IMPACT ANALYSIS

A thesis submitted in partial fulfillment of the

requirements for the degree of

MASTER OF SCIENCE

in

ENVIRONMENTAL STUDIES

by

Mehrnoosh Asadi

2016 
To: Dean Michael R. Heithaus

College of Arts, Sciences and Education

This thesis, written by Mehrnoosh Asadi, and entitled Evaluating the Economic Impact of Recreational Charter Fishing in Florida Using Hedonic Price and Economic Impact Analysis, having been approved in respect to style and intellectual content, is referred to you for judgment.

We have read this thesis and recommend that it be approved.

$\begin{array}{r}\hline \text { Mahadev G. Bhat } \\ \hline \text { Mennifer Rehage } \\ \hline \text { Pallab Mozumder, Major Professor }\end{array}$

Date of Defense: July 6, 2016

The thesis of Mehrnoosh Asadi is approved.

Dean Michael R. Heithaus

College of Arts, Sciences and Education

Andrés G. Gil

Vice President for Research and Economic Development and Dean of the University Graduate School

Florida International University, 2016 
(C) Copyright 2016 by Mehrnoosh Asadi All rights reserved. 


\section{DEDICATION}

I dedicate this thesis to my beloved parents, Masoumeh and Mohsen Asadi and to my loving sister and brother Nooshin and Mehran. You have successfully made me the person I am becoming. 


\section{ACKNOWLEDGMENTS}

Foremost, I would like to express my sincere gratitude to my advisor, Dr. Pallab Mozumder, for the continuous support of my graduate study and research, for his patience, motivation, enthusiasm, and immense knowledge. His guidance helped me in all the time of research and writing of this thesis. I truly would like to thank him for allowing me to work in the South Florida Water, Sustainability, and Climate project (NSF Award\# 1204762). I could not have imagined having a better advisor and mentor for my graduate study. I also thank my other thesis committee members, Dr. Michael Sukop, Dr. Mahadev Bhat, and Dr. Jennifer Rehage, for their encouragement and insightful comments. My sincere thanks also go to Department of Earth and Environment and Dr. Krish Jayachadran for offering me the assistantship that allowed me to complete my master’s degree. Finally, I want to sincerely thank Dr. Kianoosh G. Boroojeni for his helpful feedback on my thesis. 


\author{
ABSTRACT OF THE THESIS \\ EVALUATING THE ECONOMIC IMPACT OF RECREATIONAL CHARTER \\ FISHING IN FLORIDA USING HEDONIC PRICE AND ECONOMIC IMPACT \\ ANALYSIS \\ by \\ Mehrnoosh Asadi
}

Florida International University, 2016

Miami, Florida

Professor Pallab Mozumder, Major Professor

Florida is the "Fishing Capital of the World". With 3.1 million recreational anglers and total recreational fishing-related expenditures of $\$ 5$ billion in 2011, Florida ranked first in the nation. Given the large benefits of recreational fishing in Florida, assessing the preferences of anglers is critical for sustaining the substantial benefits obtained from recreational fishing in Florida. The objective of this study is to estimate the value of fishing attributes using data on recreational fishing services offered by guides and outfitters. Hedonic price models are applied to estimate the implicit prices of fishing trip attributes and features. The estimated total economic impacts suggest that recreational fishing activities have added \$151.19 million value to the economy of Florida and generated $\$ 69.73$ million in total output. The results can be used by state and national policymakers for future policy design and management of this unique ecosystem service to ensure a sustainable economy. 


\section{TABLE OF CONTENTS}

CHAPTER

PAGE

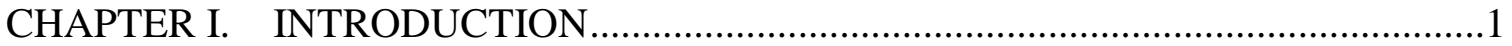

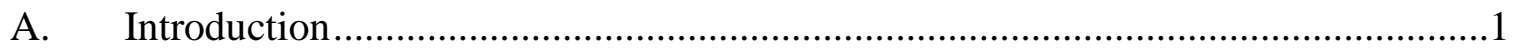

B. Participation in Recreational Fishing in the US ................................................2

C. Recreational Fishing and its Economic Importance in Florida...............................3

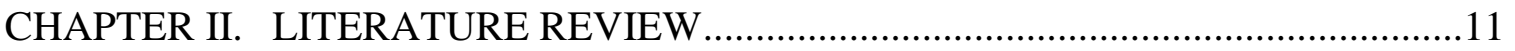

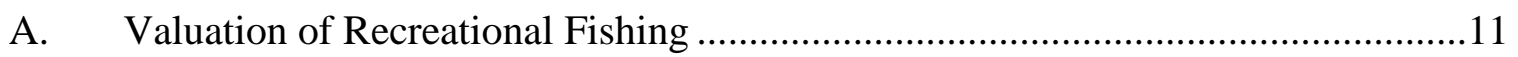

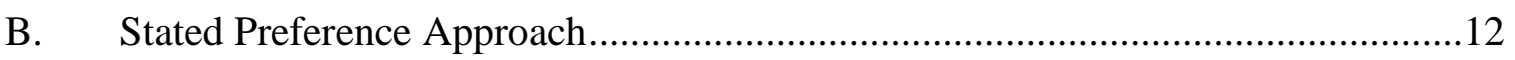

2.B.1. Contingent Valuation Method (CVM) .......................................................12

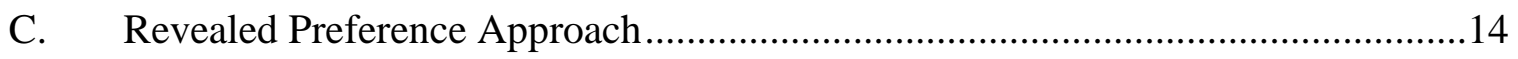

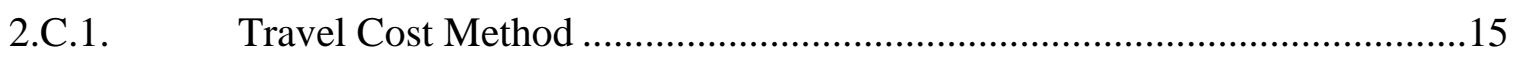

2.C.2. Random Utility Model ...................................................................... 16

2.C.3. Hedonic Price Analysis ..................................................................... 17

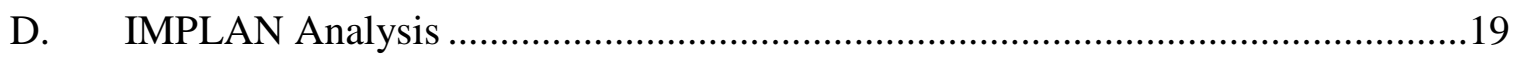

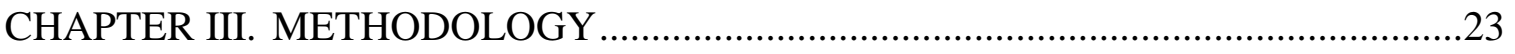

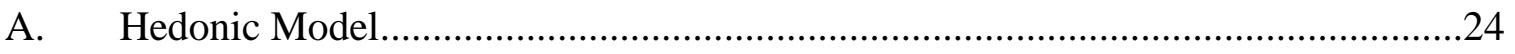

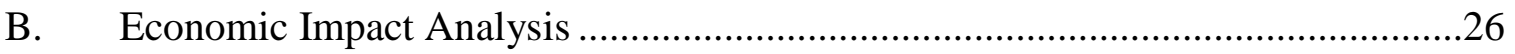

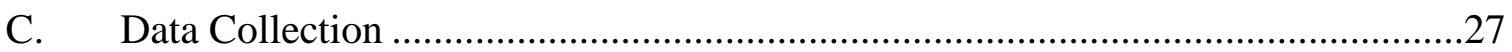

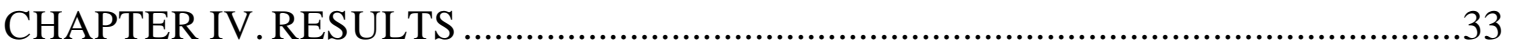

A. Descriptive Statistics of Recreational Trip Database...........................................33

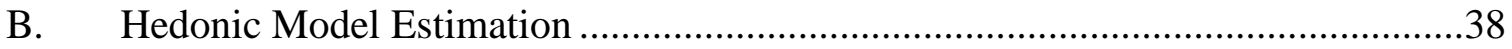

4.B.1. Freshwater Recreational Fishing Model Construction ..............................40

4.B.2. Saltwater Inshore Recreational Fishing Model Construction .....................41

4.B.3. Saltwater Offshore Recreational Fishing Model Construction ....................43

4.B.4. Final Estimated Hedonic Model ..............................................................43

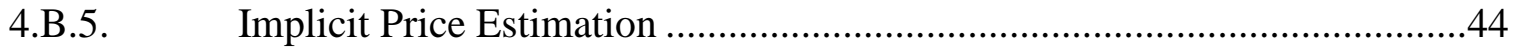

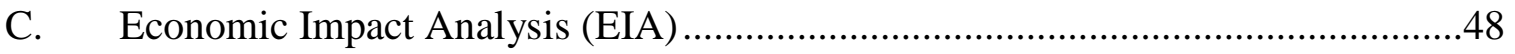

CHAPTER V. DISCUSSION AND CONCLUSION ..................................................54 
REFERENCES.. 


\section{LIST OF TABLES}

TABLE

PAGE

Table 1: Participation in Wildlife-associated Recreation Activities ..................................3

Table 2: Comparison of Anglers Population and Fishing Days (2011) in 13 States...........5

Table 3: Top 10 States Ranked by Anglers’ Expenditures ............................................6

Table 4: Total Expenditures by Categories and Regions in Florida, 2011 (\$1,000s) ..........7

Table 5: Classification of Valuation Approaches. ..........................................................12

Table 6: National Marine Fisheries Service (NMFS) Socio-economic Surveys for

Recreational Fishing Classified by Year and Location................................................15

Table 7: Definition of the Variables Used in the Proposed Model.................................29

Table 8: List of the Most Influential Industry Sectors in Recreational Charter Fishing....32

Table 9: Descriptive Statistics of the Trip Characteristics Variables. ..............................36

Table 10: Descriptive Statistics of the Dummy Variables Attributes...............................37

Table 11: Semi-Log Hedonic Models for Freshwater, Saltwater Inshore, and Saltwater

Offshore Fishing Trip Prices......................................................................................42

Table 12: Implicit Price Estimation .......................................................................45

Table 13: List of Charter Fishing Expenses and Their Associated IMPLAN Sectors.......49

Table 14: Top Eight Industry Sectors Affected Recreational Charter Fishing in Florida .50

Table 15: Detailed Comparison of Economic Impact Analysis of Florida Recreational Charter Fishing Based on Our Results in 2015 with the Results of Savolainen et al. (2014)

Table 16: Social Accounting Matrix (SAM) Multipliers for Fishing Expenditures of Florida Recreational Fisheries. 


\section{LIST OF FIGURES}

FIGURE

Figure 1: Column Chart of Recreational Charter Fishing Based on the Seller and

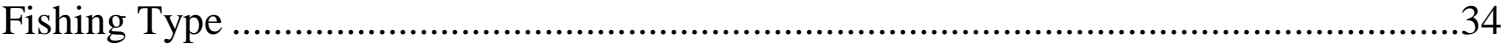

Figure 2: Doughnut Chart of Inshore, Nearshore, and Offshore Fishing Trip Packages...35

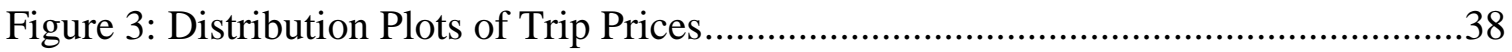

Figure 4: Distribution Plots of Trip Price per Person per Hour ......................................39

Figure 5: Comparison of Price Distribution for Freshwater, Saltwater Inshore and

Saltwater Offshore Trips for Recreational Fishing in Florida. 40 


\section{ABBREVIATIONS AND ACRONYMS}

\begin{tabular}{|c|c|}
\hline ASA & American Sport Fishing Association \\
\hline CVM & Contingent Valuation Method \\
\hline FFWCC & Florida Fish and Wildlife Conservation Commission \\
\hline FW & Freshwater \\
\hline HM & Hedonic Model \\
\hline HP & Hedonic Price \\
\hline NMFS & National Marine Fisheries Service \\
\hline RUM & Random Utility Model \\
\hline STD & Standard Deviation \\
\hline SAM & Social Accounting Matrix \\
\hline SW & Saltwater \\
\hline SWI & Saltwater Inshore \\
\hline SWO & Saltwater Offshore \\
\hline TCM & Travel Cost Method \\
\hline USFWS & US Fish and Wildlife Services \\
\hline WTP & Willingness to Pay \\
\hline
\end{tabular}




\section{CHAPTER I. INTRODUCTION}

\section{A. Introduction}

Recreational fishing is becoming more important in marine fisheries management, especially because of its impact on the economy. As a result of its positive influence on the economy, there has been an increase in the number of recreational fishermen and consequently, the amount of fish caught through recreational fishing (Steinback et al., 2004; Kearney, 2002; Coleman et al., 2004). The increase of demand for more recreational activities, (like recreational fishing) can be explained by an increase in income per person, a decrease in work hours, and an increase in the number of annual holidays. Additionally, enhancement of individuals’ degree of education in developed countries would result in an increase in demand for recreational fishing activities (Tisdell, 2003).

Every year, many Americans participate in outdoor recreational activities, especially fishing. According to the US Outdoor Recreation Participation Report (ORPR, 2015), fishing, with 31.4 million participants, has been ranked number two among the most popular adult activities after running, jogging, and trail running, with 33 million participants in 2015. The United States is the only country that has collected data on participants engaged in recreational fishing and their related expenses in this market over almost 50 years (Tisdell, 2003). It has shown that recreational fishing, compared to commercial fishing, has become increasingly important in the past 50 years (National Research Council [NRC], 2006; Cooke \& Cowx, 2006). 


\section{B. Participation in Recreational Fishing in the US}

According to the National Surveys conducted by the US Fish and Wildlife Service, the number of Americans participating in recreational fishing doubled in the period of 1955 to 2001 (US Fish and Wildlife Service [USFWS], 2001). In this time period, the US economy experienced substantial growth. In 2001, 16 percent of Americans participated in recreational fishing, compared to nine percent in 1955 (Tisdell, 2003). Based on the National Survey of Fishing, Hunting, and Wildlife-Associated Recreation (USFWS, 2011), 33 million adult anglers participated in recreational fishing in the United States in 2011. Former surveys by the USFWS specified that 28.6 percent of people participating in recreational fishing activities were younger than 16 years of age (USFWS, 2011). Also, the surveys of state fishing licenses showed that many fishermen do not buy a fishing license every year (American Sportfishing Association [ASA], 2013). As a result, about $33 \%$ to $50 \%$ of anglers in the US could not go fishing for this reason. The American Sport Fishing Association (ASA, 2013) estimated that 60 million Americans call themselves fishermen even if they don’t have a fishing license. According to Table 1, the number of participants in recreational fishing activities has grown 11 percent from 29.952 million in 2006 to 33.112 million in 2011.

Based on the 2011 National Survey of Fishing, Hunting and Wildlife-Associated Recreation, more than 33 million individuals who were 16 or older participated in recreational fishing, and spent $\$ 48$ billion on fishing-related expenditures (including guides' fee, fishing equipment, accommodation, etc.). These expenditures helped the economy to generate more than 828,000 jobs worth $\$ 35$ billion in the form of salaries and wages (ASA, 2013). The rising number of anglers causes economic growth as it increases 
the purchase of fishing licenses, supports the operations of state fish and wildlife organizations, and contributes to the federal excise tax on fishing tackle, the Sport Fish Restoration Program, and the Boating Trust Fund (ASA, 2013).

Table 1: Participation in Wildlife-associated Recreation Activities

\begin{tabular}{|l|l|l|l|l|}
\hline & 2006 & 2011 & \\
& $\begin{array}{l}\text { Number } \\
(1000 \text { 's })\end{array}$ & $\begin{array}{l}\text { Percent } \\
(\%)\end{array}$ & $\begin{array}{l}\text { Number } \\
(1000 \text { 's })\end{array}$ & $\begin{array}{l}\text { Percent } \\
(\%)\end{array}$ \\
\hline Total wildlife-related recreationists & 87,465 & 100 & 90,108 & 100 \\
\hline Total sportspersons & 33,916 & 39 & 37,397 & 42 \\
\hline -Anglers & 29,952 & 34 & 33,112 & 37 \\
\hline -Hunters & 12,510 & 14 & 13,674 & 15 \\
\hline Total wildlife watching participants & 71,132 & 81 & 71,776 & 80 \\
\hline -Around the home & 67,756 & 77 & 68,598 & 76 \\
\hline -Away from home & 22,977 & 26 & 22,496 & 25 \\
\hline
\end{tabular}

Source: (USFWS, 2011)

\section{Recreational Fishing and its Economic Importance in Florida}

Based on the Florida Fish and Wildlife Conservation Commission (FFWCC, 2016a) and according to 2011 National Survey of Fishing, Hunting, and Wildlifeassociated Recreation (USFWS, 2011), Florida is the fishing capital of the world due to its enormous fishing resources and its effective sport fishing management activities. Moreover, several targeted fish species, fishing destinations, year-round angling, strong tourism, and business-related character have made Florida one of the most attractive destinations for fishing-based recreational activities (FFWCC, 2016a). 
Every five years, the U.S. Fish and Wildlife Service conducts a survey to compare outdoor recreational activities over time in different states. Both the 2006 and 2011 surveys revealed that Florida is the state with the highest fishing-related economic activities. The findings from the aforementioned survey result in a good understanding of the population of anglers and the time they spend fishing in different states.

As Table 2 illustrates, the state of Florida had the highest number of recreational fishing days among the U.S. states in 2011 (about 27 million days more than Texas, which has the second largest population of recreational anglers). Additionally, Florida hosted more non-resident anglers than other states (approximately 1.2 million anglers). Generally speaking, Florida had the highest adult fishermen population, with three million anglers who have spent $\$ 5$ billion in 2011. Texas had the second largest anglers’ population (760 thousand anglers less than Florida). The economic impact of recreational fishing has created 80,211 jobs in Florida, while Michigan gained 37,989 jobs and ranked second in job creation from recreational fishing (ASA, 2013). Moreover, Table 3 shows the top 10 states ranked by anglers' fisheries-related expenditures in 2013.

In 2011, according to US Fish and Wildlife Service National Fishing License Report (USFWS, 2015), 1,866,045 fishing licenses were sold in Florida. The difference between the number of issued licenses and the number of total anglers ( 3 million) is mostly because anglers older than 65 and those residing on saltwater coastlines, in addition to a few more minor groups are exempt from having fishing license (FFWCC, 2016b). Recreational anglers hire both fishing equipment and fishing guides as parts of a major industry in the Gulf Coast and South Atlantic coast (Kearney et al., 2014). 
Table 2: Comparison of Anglers Population and Fishing Days (2011) in 13 States.

\begin{tabular}{|c|c|c|c|c|c|c|c|c|}
\hline & $\begin{array}{l}\text { Total } \\
\text { Anglers } \\
\text { (1000s) }\end{array}$ & $\begin{array}{l}\text { Non- } \\
\text { Resident } \\
\text { Anglers } \\
\text { (1000s) }\end{array}$ & $\begin{array}{l}\text { Total } \\
\text { Fishing } \\
\text { Days } \\
\text { (1000s) }\end{array}$ & $\begin{array}{l}\text { Non-Resident } \\
\text { Fishing Days } \\
\text { (1000s) }\end{array}$ & $\begin{array}{l}\text { FW }^{1} \\
\text { Anglers } \\
(1000 s)\end{array}$ & $\begin{array}{l}\text { FW } \\
\text { Fishing } \\
\text { Days } \\
\text { (1000s) }\end{array}$ & $\begin{array}{l}\mathrm{SW}^{2} \\
\text { Anglers } \\
\text { (1000s) }\end{array}$ & $\begin{array}{l}\text { SW } \\
\text { Fishing } \\
\text { Days } \\
\text { (1000s) }\end{array}$ \\
\hline FL & 3,092 & 1,197 & 57,594 & 9,544 & 1,214 & 25,729 & 2,398 & 36,348 \\
\hline TX & 2,246 & 114 & 30,667 & 1,095 & 1,758 & 22,616 & 751 & 157 \\
\hline$\overline{\mathrm{MI}}$ & 1,744 & 347 & 28,177 & 2,164 & 1,361 & 20,961 & N/A & N/A \\
\hline $\mathbf{C A}$ & 1,674 & 98 & 23,754 & 487 & 1,352 & 17,382 & 775 & 7,193 \\
\hline$\overline{\mathrm{WI}}$ & 1,247 & 337 & 21,284 & 6,708 & 1,107 & 19,950 & N/A & N/A \\
\hline $\mathrm{CO}$ & 767 & 175 & 8,433 & 943 & 767 & 8,433 & N/A & N/A \\
\hline$\overline{\mathbf{A L}}$ & 683 & 210 & 10,878 & 974 & 598 & 9,746 & 134 & 1,490 \\
\hline$\overline{\mathbf{A Z}}$ & 637 & 104 & 4,825 & 684 & 637 & 4,825 & N/A & N/A \\
\hline$\overline{\mathbf{A R}}$ & 555 & 97 & 15,662 & 607 & 555 & 15,662 & N/A & N/A \\
\hline$\overline{\mathbf{A K}}$ & 538 & 327 & 4,360 & 1,287 & 302 & 2,995 & 334 & 1,446 \\
\hline$\overline{\mathrm{UT}}$ & 414 & 70 & 5,979 & 606 & 414 & 5,979 & N/A & N/A \\
\hline$\overline{\mathrm{CT}}$ & 342 & 65 & 4,705 & 310 & 243 & 3,518 & 165 & 1,291 \\
\hline$\overline{\mathrm{DE}}$ & 166 & 107 & 2,052 & 724 & 55 & 655 & 138 & 1,339 \\
\hline
\end{tabular}

Source: National Survey of Fishing, Hunting and Wildlife-Associated Recreation, (USFWS, 2011).

In 2013, the National Marine Fisheries Service conducted a survey regarding marine recreational fishing expenditures (Lovel et al., 2013). Anglers’ expenditures in Florida were divided into two parts: East Florida and West Florida. In East Florida, the total anglers’ expenses on marine recreational fishing were estimated to be \$3.8 billion in 2011. In the same year, Trip-related expenditures were \$355 million and for-hire fishing trip expenditures (fishing trips provided by guides and outfitters) were estimated to be \$51 million. Additionally, in West Florida, the total recreational fishing totaled \$5.5

\footnotetext{
${ }^{1}$ Freshwater (FW): In this thesis, freshwater fishing is referred to the type of fishing aiming to catch freshwater fish. The anglers participating in freshwater fishing are referred to as freshwater anglers.

${ }^{2}$ Saltwater (SW): In this thesis, saltwater fishing is referred to the type of fishing aiming to catch saltwater fish. The anglers participating in saltwater fishing are referred to as saltwater anglers.
} 
billion and for-hire fishing trip expenditures were estimated to be \$187 million in 2011 (See Table 4).

Table 3: Top 10 States Ranked by Anglers’ Expenditures

\begin{tabular}{|l|l|l|l|}
\hline Rank & State & Expenditures (million USD) & Number of Anglers (1000's) \\
\hline $\mathbf{1}$ & FL & 4,953 & 3,092 \\
\hline $\mathbf{2}$ & NY & 2,697 & 1,882 \\
\hline $\mathbf{3}$ & MI & 2,466 & 1,744 \\
\hline $\mathbf{4}$ & MN & 2,440 & 1,562 \\
\hline $\mathbf{5}$ & CA & 2,394 & 1,674 \\
\hline $\mathbf{6}$ & TX & 2,014 & 2,246 \\
\hline $\mathbf{7}$ & OH & 1,904 & 1,342 \\
\hline $\mathbf{8}$ & NC & 1,656 & 1,525 \\
\hline $\mathbf{9}$ & WI & 1,460 & 1,247 \\
\hline $\mathbf{1 0}$ & VA & 1,407 & 833 \\
\hline
\end{tabular}

Source: (ASA, 2013)

The amount that resident and non-resident anglers in Florida spent on for-hire recreational fishing is $\$ 238$ million. Based on Table 4, many factors contribute to recreational fishing trip expenditure (including charter fees, tournament fees, bait, food and lodging etc.). Moreover, charter fees are the highest expenditures for resident and non-resident anglers in Florida with \$25.9 and \$91.0 million respectively. There is no study on Florida anglers’ preferences for different fishing trip characteristics in choosing hire fishing or private fishing. In fact, there is an important unanswered question regarding for-hire fishing trips in Florida that needs to be addressed: Which factors (including the combination of specific fish species, lodging options, fishing destinations, etc.) would influence the anglers' choice for a specific type of hire-fishing package? 
Table 4: Total Expenditures by Categories and Regions in Florida, 2011 (\$1,000s)

\begin{tabular}{|c|c|c|c|c|c|c|}
\hline \multirow[b]{2}{*}{ Expenditure Category } & \multicolumn{3}{|c|}{ East Florida } & \multicolumn{3}{|c|}{ West Florida } \\
\hline & $\begin{array}{l}\text { Resident } \\
(1000 \$)\end{array}$ & $\begin{array}{l}\text { Non-Res. } \\
(1000 \$)\end{array}$ & $\begin{array}{l}\text { Total } \\
(1000 \$)\end{array}$ & $\begin{array}{l}\text { Resident } \\
\text { (1000 \$) }\end{array}$ & $\begin{array}{l}\text { Non-Res. } \\
(1000 \$)\end{array}$ & $\begin{array}{l}\text { Total } \\
(1000 \$)\end{array}$ \\
\hline Auto Fuel & 436 & 5,784 & 6,220 & 1,568 & 16,684 & 18,252 \\
\hline Auto Rental & 0 & 3,082 & 3,082 & 0 & 8,270 & 8,270 \\
\hline Bait & 0 & 0 & 0 & 0 & 25 & 25 \\
\hline Boat Rental & 0 & 0 & 0 & 0 & 47 & 47 \\
\hline Charter Fees & 4,108 & 17,299 & 21,407 & 21,772 & 73,727 & 95,499 \\
\hline Crew Tips & 456 & 4,375 & 4,831 & 1,749 & 8,736 & 10,485 \\
\hline Fish Processing & 0 & 558 & 558 & 0 & 50 & 50 \\
\hline Food (Grocery Stores) & 151 & 1,158 & 1,309 & 1,117 & 4,629 & 5,746 \\
\hline Food (Restaurants) & 178 & 2,010 & 2,188 & 1,458 & 11,077 & 12,535 \\
\hline Gifts and Souvenirs & 0 & 1,209 & 1,209 & 78 & 5,080 & 5,158 \\
\hline Ice & 0 & 0 & 0 & 7 & 25 & 32 \\
\hline Lodging & 0 & 6,868 & 6,868 & 1,179 & 18,746 & 19,925 \\
\hline Parking/Access Fees & 0 & 176 & 176 & 8 & 57 & 65 \\
\hline Public Transportation & 0 & 2,876 & 2,876 & 48 & 11,156 & 11,204 \\
\hline Tournament Fees & 0 & 0 & 0 & 0 & 0 & 0 \\
\hline For-Hire Trip Total & 5,329 & 45,395 & 50,724 & 28,984 & 158,309 & 187,293 \\
\hline
\end{tabular}

Source: (Lovel et al., 2013)

Each fisherman who has a state fishing license can go fishing and choose a fishing trip package including different characteristics. It is hard to analyze the anglers’ preferences for fishing trip features by merely knowing the price of the state's license fees, starting from $\$ 17.00$ (for 3-day freshwater/saltwater fishing trips) to $\$ 47.00$ (for annual freshwater/saltwater fishing trips) (FFWCC, 2016b). However, Florida guides and outfitters provide the anglers with different fishing trip packages. The guides’ market offers heterogeneous fishing trips with different price and qualities of service (Pitts et al., 2012). 
There are considerable recreational fishing studies that study anglers' willingness to pay (WTP) utilizing contingent valuation methods ${ }^{3}$ (CVM) and travel cost methods ${ }^{4}$ (TCM). In both methods, the WTP is not quantified by real market data; in fact, CVM and TCM use hypothetical substituted and proxy market prices. For example, TCM considers availability and harvest values created based on the substitution of distance and time required to reach fishing spots (Carter et al., 2008). Thus, quantified values using CVM and TCM are accurate if the substituted prices are correct. The Hedonic Price ${ }^{5}$ (HP) analysis can result in a better understanding of a market by dividing the actual price of a heterogeneous good into the marginal implicit prices of its different characteristics (Pitts et al., 2012).

Although there exist a considerable number of research studies evaluating the economic impact of recreational fishing in the US and other countries, there is not much variety in the methods used by researchers to obtain the fishing-related expenditures in order to compute the economic impact of recreational fishing market. In fact, the expenditures are either obtained by online data available on the web, first-handed or second-handed surveys. Some of the fishing-related expenditures like captain license fees and boat registration fees are easy to obtain as they are specified by governmental agencies or other large-scale organizations. However, there are some expenditures (e.g. lodging) that are highly dependent on various fluctuating markets like hoteling.

\footnotetext{
${ }^{3}$ Contingent valuation method estimates an individual willingness to pay for having a specific good through making a hypothetical market.

${ }^{4}$ Travel cost method estimates the value of recreational sites by relating the site access frequency to its price.

${ }^{5}$ Hedonic analysis is utilized in a market where a heterogeneous good and service with different characteristics generates different prices in the market
} 
Moreover, some of the charter-fishing expenditures (e.g., fuel cost) are too stochastic to be accurately estimated by guides and outfitters as they vary from trip to trip. In these circumstances, using survey methods may lead to inaccurate information, while, online resources may provide insufficient information. As a novel contribution of this study, we utilize the Hedonic price model for evaluating the expenditures spent on lodging and boat fuel in a recreational charter fishing market. By modeling the trip price as a Hedonic function of multiple independent variables including fuel cost and dummy-variable of lodging, we are able to evaluate the marginal impact of these variables on the price which leads to the constant-value estimation of their corresponding expenditures in a trip.

The present study seeks to analyze the variations in fishing trip prices, offered by Florida fishing guides and outfitters utilizing hedonic price analysis. The goal of our study is to quantify the effect of a wide variety of fishing trip attributes on the variation of fishing trip prices offered by guides and outfitters. In the first step, we collect data utilizing the information provided online by the guides and outfitters (also by calling them in person). After cleaning and processing the collected data, we estimate the empirical relationships between trip prices and other associated variables (like fish species, guide characteristics, fuel cost, food, lodging, etc.). After building the model (using STATA and R software), we are able to estimate the implicit price of every variable participating in the fishing trip model. Some of the computed implicit prices are then used for estimating the for-hire fishing trip expenditures spent on food and accommodation which have volatile unpredictable markets and consequently, cannot be easily evaluated based on online prices. The estimated expenditures along with other forhire fishing expenditures obtain online from the FWC website (FFWCC, 2016b) lead us 
to evaluate the economic impacts of recreational charter fishing in Florida using IMPLAN software. The results of the economic impact analysis of recreational charter fishing in Florida can be used by state and national policymakers for future policy design and management of this unique ecosystem service to ensure a sustainable economy. 


\section{CHAPTER II. ITTERATURE REVIEW}

\section{A. Valuation of Recreational Fishing}

In order to address fisheries management concerns, non-market valuation approaches have been used (Lipton et al., 2014). Considering the lack of market transaction data on fisheries-related expenditures, most studies have utilized non-market valuation methods for valuing anglers’ preferences in the recreational fishing sector. Moreover, the National Standard 5 under the Magnuson-Stevens Fishery Conservation and Management Act (MSFCMA) requires measurements of market- and non-marketbased economic value to ensure the effectiveness of conservation and management actions (Lipton et al., 2014). The benefits of recreational fishing are defined as the values that anglers obtain from various recreational fishing practices and estimated utilizing recreational demand models (Raguragavan et al., 2013).

As listed in Table 5, there are different methods that are used for nonmarket valuation of recreational fishing: the contingent valuation method (as a stated preference approach), the travel cost model and the hedonic model (as revealed preference approaches) (Johnston et al., 2006). In the rest of Chapter II, we explain the application of different methods used to assess recreational fishing such as CVM, TCM, and HM. We elaborate on HM as a preferred method to assess the value of fishing practices utilizing market data provided by guides and outfitters for recreational fishing packages (Carter et al., 2008). 
Table 5: Classification of Valuation Approaches.

\begin{tabular}{|l|l|} 
& Revealed Preferences \\
\hline & Competitive market prices \\
\hline & Simulated market prices \\
\hline & Household production function models \\
\hline Time allocation \\
\hline Random utility and travel cost \\
\hline Hedonics \\
\hline Production function models \\
\hline Referendum votes
\end{tabular}

\section{Stated Preferences}

Contingent valuation, open-ended response format

Contingent valuation, discrete-choice and interval response format

Contingent behavior

Conjoint analysis (attribute-based)

Source: (Freeman 1993)

\section{B. Stated Preference Approach}

The stated preference approach can be used for different purposes, including studying different kinds of anglers' behaviors, investigating preferences for fish species and associated trade-offs, evaluating responses to different types of management schemes, assessing various environmental problems, and valuation of fishing activities (National Marine Fisheries Services [NMFS], 2016).

\section{B.1. Contingent Valuation Method (CVM)}

The contingent valuation method (CVM) is a stated-preference approach that is used for estimating the value of recreational activities. CVM is based on willingness to pay reported by individuals stating what they want to pay for protection of a specific environmental resource (Graeven, 2013). In these cases, hypothetical bias may happen when there are differences between what an individual wants to pay in reality and what 
she states in the survey. There are some concerns in using CVM, especially if the survey is focused on non-market resources and public goods (Loomis, 2014).

Johnston et al. (2006) conducted a meta-analysis of recreational fishing values based on willingness to pay per fish in the U.S. and Canada utilizing CVM, TCM and RUM. The data was gathered from over 450 journal articles, academic working papers, reports, books, and dissertations related to nonmarket valuation studies. Finally, 48 studies were considered for the analysis. The results showed that the WTP varies based on the resource, situation, fisherman characteristics, and the methodology.

A large number of studies have been conducted nationwide using CVM to value recreational fishing goods and services in the US. Hamel et al. (2000) utilized TCM and CVM methods to estimate the value of the marine halibut and salmon sport fishery in central and lower Cook Inlet in Alaska. The result showed that the halibut and salmon fishery in the Kenai Peninsula produced 259,615 saltwater angler-days in central and lower Cook Inlet, which was valued at $\$ 37.4$ million in 1997. The study by Thomas et al. (1986) used CVM to investigate the economic importance of marine recreational fishing in southern California. The study revealed that the economic value of recreational fishing in southern California is around \$2,087.07 million (in 2010 dollar value). Berrens et al. (1993) estimated the recreational fishing demand in an urban area for Chinook salmon in Oregon. Based on this study, the marginal value of Chinook salmon was estimated at \$3.99 per fish (in 2003 dollar value). In Tennessee, Williams et al. (2003) conducted a study to estimate the consumer surplus of trout fishing in eight Tennessee tailwaters by applying the TCM and CVM approaches. The results showed that the value estimated by 
CVM were higher than TCM for the same fisheries and varied from \$42.27 per angler per day on the Duck River to $\$ 91.69$ per angler per day on the Watauga River.

A large number of valuation studies focusing on recreational fishing have been conducted in the Southern US, especially in Florida. Bell et al. (1982) applied CVM to estimate the economic impact and total value of all saltwater recreational fisheries in Florida. The results showed that the estimated consumer surplus per day for residents and no-residents are \$82.9 and \$61-\$77 respectively. McConnell and Strand (1994) used both CVM and TCM to evaluate the economic benefits of recreational fishing in the MidAtlantic and South-Atlantic states (from New York to Florida).

The National Marine Fisheries Service (NMFS) makes a major contribution to facilitating research on recreational fishing by conducting socio-economic surveys (Lipton et al., 2014). In 1996, NMFS started conducting revealed-preference approaches surveys and added them to Marine Recreational Fisheries Statistics Survey (MRFSS), which could then be used in more accurate random utility models (Lipton et al., 2014). Table 6 gives a summary of the years when NMFS conducted different surveys on recreational fishing in different areas in the US.

\section{Revealed Preference Approach}

The revealed-preference models provide a better understanding of recreational anglers' decisions and associated economic benefits. From a fisheries management perspective, these models can be used to estimate the economic benefits of different management options. They are also useful for assessing different plans that influence fisheries, including ecosystem management plans (NMFS, 2016). 
Table 6: National Marine Fisheries Service (NMFS) Socio-economic Surveys for Recreational Fishing Classified by Year and Location

\begin{tabular}{|l|l|l|}
\hline Region & Revealed Preference Surveys & Stated Preference Surveys \\
\hline Alaska & $2002,2004,2006,2011$ & $2002,2007,2011$ \\
\hline Atlantic & 2011 & \\
\hline Caribbean & $2003 / 2004$ & $2003 / 2004$ \\
\hline Northeast & $\begin{array}{l}1996,1997,1999,2000,2006,2009, \\
2011\end{array}$ & $2000,2009,2010,2012$ \\
\hline Pacific Islands & 2006,2011 & 2006 \\
\hline Southeast & $\begin{array}{l}1999,2000,2003 / 2004,2006,2009, \\
2011\end{array}$ & $2003 / 2004,2009$ \\
\hline West Coast & $1998,2001,2006,2009$ (CA), 2011 & 2006, 2009 (CA), 2013 (WA) \\
\hline
\end{tabular}

Source: (Lipton et al., 2014)

\section{C.1. Travel Cost Method}

The TCM suggested by Hotelling (1974) is based on the fact that the number of visitors to a recreational destination decreases if the cost of trip increases (Ward and Beal, 2000). The advantages of using the TCM are that it is related to consumer theory, and it relies on market data to measure the travel cost (Smith, 1989; Smith, 1993). The TCM has been used to estimate the consumer surplus related to the marine recreational fishing. Kaval and Loomis (2003) identified 129 valuation studies of recreational fishing in the US and Canada from 1967 to 2003. Also, Johnston et al. (2006) found more than 450 non-market valuation studies which have estimated recreational fishing values in the US, Canada, and Europe.

Agnello (1989) conducted research to estimate the consumer surplus for blue fish and flounder caught by anglers in states along the Atlantic Coast from New York to Florida. The value for a blue fish and a flounder were estimated as $\$ 0.74$ and $\$ 3.54$ respectively. In terms of recreational fishing in salt marshes, Bockstael et al. (1989) 
applied the TCM to evaluate the compensating variation for access to fishing sites in nine counties of Florida. In terms of beach access for recreational fishing, Bell and Leeworthy (1990) estimated consumer surplus of recreation at saltwater beaches in Florida using the TCM and the value was estimated as $\$ 34$ per day.

\section{C.2. Random Utility Model}

The TCM and CVM are two methods which have been used widely to estimate the value of recreational activities, especially recreational fishing and sea angling. However, the random utility model (RUM) approach has been also used for valuing recreational fishing (Graeven, 2013). Numerous recreational fishing studies have been conducted utilizing RUM in the United States and Canada as well as in European countries (Lew \& Larson, 2005; Navrud, 1999; Adamowicz, 1994; Walsh et al., 1992). Loomis et al. (1999) reviewed 109 studies that applied consumer surplus RUM and other methods in order to estimate the value of recreational activities in the US.

Also, there are a number of studies in the UK that have utilized RUM to estimate the value of recreational fishing. Lawrence (2005) applied RUM to evaluate the value of recreational sea fishing experiences in Southwest England. He found that the size of each fish has a greater impact on value than catch rate per day. Raguragavan et al. (2013) used the national survey data including 48 fishing sites and 8 major fishing areas to analyze angling site selections in Western Australia. They used RUM to relate the fishing site selection to site specific attributes and fishermen characteristics. The results showed that the amount of fish caught, travel cost, and shore distance had statistically significant effects on fishing site selection. 


\section{C.3. Hedonic Price Analysis}

There is a large body of research focused on anglers’ willingness to pay (WTP) utilizing CVM and TCM. As mentioned earlier, in both methods, the value is not quantified by real market data, but rather using a hypothetical market price for CVM and a substitute or proxy price for TCM. For example, TCM considers availability and harvest values created based on the substitution of distance and time required to reach fishing spots (Carter et al., 2008). Thus, quantified values are accurate as long as substituted prices are correct. These concerns in non-market valuation using TCM are mentioned in Randall (1994) and Englin and Shonkwiler (1995). The hedonic price analysis can help in understanding a market by dividing the actual price differences of a heterogeneous good into marginal implicit prices of its different characteristics (Pitts et al., 2012).

A number of characteristics, e.g., fish species, environmental features, other public and private goods characteristics, exist in all fishing trip options, meaning that any fisherman who buy a state license and chooses a fishing spot for his own trip indirectly puts value on the package of features accessible at their selected location. It is obvious that we will face problems if we estimate these anglers’ values for fishing trip characteristics from a state's license prices only. However, guides and outfitters provide similar fishing services as those selected by the solo angler (Pitts et al., 2012).

A few studies have used the hedonic price analysis to assess the value of anglers’ willingness to pay for different characteristics of fishing trips. A revealed-preference approach based on the HP analysis has been used by Livengood (1983) who calculated the value of deer harvested by lease hunters in Texas. Likewise, Taylor and Marsh (2003) 
conducted a study in Kansas to examine how much the market price for a hunting permit can be affected by different characteristics of the hunting permit, spatial factors, and the socioeconomic characteristics of the deer hunters. In 2008, a similar study was conducted by Little and Berrens to analyze the regional market for elk hunting permits and other associated hunting services in the Southwest United States. The next year, in order to value auctioned hunting leases in Mississippi, Rhyne et al. (2009) evaluated factors affecting the value of hunting leases on sixteen zones in Mississippi by applying hedonic analysis.

In recent years, the hedonic model has been applied in some fishing-related research works. For instance, by applying a hedonic price model, Carter et al. (2008) analyzed the differences in charter trip prices, which can be attributed to variations in trip and harvest features across charters' fishing locations in the Gulf of Mexico. Later, Pitts et al. (2012) applied a hedonic model to assess anglers’ values for associated characteristics of trout fishing trips offered by outfitters in Montana, Wyoming, Colorado, and New Mexico. These values are quantified by marginal implicit prices for each characteristic of trout fishing trips in those states. The outfitter market in Florida offers heterogeneous fishing packages where price differences may reflect the value of associated trip characteristics. Since no study has been conducted to evaluate the prices for these varying trip characteristics, it would be an important contribution to apply the hedonic model as a revealed-preferences approach to analyze the role of these diverse trip characteristics in explaining the prices of recreational fishing trip packages. 


\section{IMPLAN Analysis}

Recreational fishing has a significant impact on the U.S. economy. According to Outdoor Recreation Participation Report in the U.S. (ORPR, 2015), recreational fishing ranked number two among the most popular adult activities (USFWS, 2011). Moreover, based on the 2011 National Survey of Fishing, Hunting and Wildlife-Associated Recreation, anglers spent \$48 billion in 2011 on various fishing-related expenditures including guides fees, equipment, accommodation, etc. The mentioned expenditures have created more than 828,000 jobs in the United States (ASA, 2013). Fishing expenditures bring considerable money and jobs in many sectors such as industry, transportation, and accommodation services (Poudel, 2014).

There are direct, indirect, and induced fishing expenditures effects on the economy. Direct effects take place if anglers pay for food, housing, transportation, and rental boats or purchase their angling gear at retail stores including buying bait, hooks, ice, and lines. Indirect effects are triggered by directly affected industries (e.g., retail and service stores) buying their needed products from local companies to provide their final goods or service. Induced effects are caused when workers directly and indirectly employed in this sector, spend their salaries purchasing local goods and services. For example if a worker employed in a recreational fishing company pays for food in a local restaurant, she has contributed to the local economy and also paid for federal and state taxes (Poudel, 2014).

A number of studies have been done to estimate the economic impact of anglers' expenditures on the local and regional economies in the US. The American Sportfishing Association (ASA, 2013) estimated the economic impact of freshwater and saltwater 
anglers' expenditures nationwide and statewide using the U.S. Fish and Wildlife Service’s (USFWS, 2011) National Survey of Fishing, Hunting and Wildlife-Associated Recreation. Based on their estimates, saltwater and freshwater anglers spent more than $\$ 30$ billion and \$13 billion respectively and generated more than 518,000 and 243,000 jobs respectively in the US in 2011. In terms of the economic impact of fish species, Fedler et al. (2007) estimated the economic impact of recreational fishing for Bonefish, Permit and Tarpons in Belize. The result showed that the total economic impact was \$25 million in 2007.

Another study focusing on the economic impact of specific fish species was published by Fedler (2010). He estimated the economic impact of Flats fishing in the Bahamas using two separate data sources. He found that Flats fishing in the Bahamas generated \$141 million in benefits to the economy of Bahama annually. Besides assessing the economic impact of angler's expenditures, there are some studies that have considered the economic impact for recreational fishing or hunting activities offered by guides and outfitters in the US and Canada. Nickerson et al. (2007) assessed the economic contribution of outfitting and guiding business including fishing and hunting trips in Montana. They estimated that almost 6,100 employment opportunities have been generated both in the form of direct jobs or contracted services (1,500 permanent occupations and 4,600 part-time jobs). Hussain et al. (2008) used a similar method to quantify regional economic impacts of wildlife-associated outfitters and their customers in Mississippi. Recently, the McDowell Group (2014) used two separate data sets to estimate the economic impacts of guided hunting in Alaska. The results indicated that 
guided hunting in Alaska generated 2,210 jobs and produced \$35 million income in 2012. As a whole, guided hunting created \$78 million in economic activities in Alaska in 2012. Outside the US, Cutlac et al. (2014) conducted a study to estimate the economic impact of guided hunting in Alberta, Canada. They developed a survey to collect the expenses payed by the outfitters and their customers on goods and services that they had to buy for guided hunting trips. They highlighted that guided hunting business activities play an important role in the economy of Alberta and have contributed \$105 million to total output of the economy. The guided hunting market also generated 460 full time positions that generated \$24.4 million in salaries and profits in Alberta.

Beside the economic impact analysis of guided hunting, there are some studies that focus on the economic contribution of fishing guides and outfitters at regional and state levels. Steinback (1999) estimated the economic impacts of expenditures of charter boat fishing in Maine in 1996. They realized that nonresident anglers using party and charter boats spent $\$ 1.12$ million in 1996 and generated a total of $\$ 1.04$ million in sales. Hodges et al. (2002) conducted a study to measure the economic impact of Florida's commercial fisheries and aquaculture industries. Elde et al. (2008) estimated the economic impact of sport fishing in Alaska. Most recently Savolainen et al. (2014) estimated the economic impacts of the recreational charter fishing industry in the Gulf of Mexico. They found that charter boats in Mississippi and Alabama generate a moderately smaller amount of total output compared to Texas, Louisiana, and West Florida.

Since no studies have been done to estimate the economic impact of recreational fishing activities offered by guides and outfitters in Florida, it is essential to know the extent of the statewide economic contribution of this market. Therefore, economic impact 
analysis of fishing trips offered by guides and outfitters would offer insights into sustainable management of this unique natural resource. The impact analysis will use the result of hedonic analysis (i.e., implicit prices). 


\section{CHAPTER III. METHODOLOGY}

In this study, we apply hedonic price analysis to estimate the value of recreational fishing activities utilizing prices for fishing trip packages provided by guides and outfitters in the state of Florida. The anglers, guides and outfitters create a market where guides and outfitters supply goods and services for recreational fishing. Recently, gaining access to various fishing guides and outfitters has become easier with the Internet, especially for non-resident anglers. They can choose their guides and outfitters based on their preferences and the fishing opportunities that they seek. Internet-based advertising has also enabled fishing guides and outfitters to easily connect with their customers (Mozumder et al., 2007).

Outfitters and guides use websites to advertise different fishing trips, highlighting various characteristics and the corresponding prices. The varieties in fishing trip characteristics provide more options for anglers to choose the one they like most. The trip

characteristics include trip duration, fishing type, fishing boat characteristics, fish species, distance of fishing destination from the shoreline and area of operation (e.g. South Florida or North Florida). Considering private fishing access, which is contracted by private landlords, outfitters and guides provide more access to fishing trip opportunities (Pitts et al., 2012). For example, in Florida, guides and outfitters sometimes include lodging in longer trip packages. These additional services generate variations in the prices of different fishing trip packages and create a monopolistically competitive private market for fishing trip access (Pitts et al., 2012). 
As the market of recreational fishing trips offered by guides and outfitters are rapidly expanding, in this study, we attempt to answer the following questions:

1. What is the revealed value or implicit price of each of these attributes in charter fishing trips? Which attributes and features of the fishing trips do the saltwater and freshwater anglers value the most?

2. How does the charter fishing market affect the economy of Florida in terms of revenue, profit, wages and jobs?

\section{A. Hedonic Model}

Our applied model was first developed by Rosen (1974). Taylor (2003) explained the application of a hedonic model in a non-market valuation context. Hedonic analysis is utilized in a market where a heterogeneous good and service with different characteristics generates different prices in the market. Thus, by conducting the HP analysis in a market offering various quality services, we can find the marginal effects of multiple service variations on the market price (Taylor, 2003).

Henceforth, the objective of our study is to analyze anglers' preferences and their values for different charter fishing trip characteristics. In order to quantify how the anglers value different characteristics of charter fishing trips led by guides and outfitters, we employ the hedonic price function, which uses a linear, semi-log, or double-log model. The price for a fishing trip is estimated as a weighted summation of trip features including the trip duration (half/full day, etc.), accommodation (food and lodging), distance of destination from shoreline (e.g., inshore/offshore), fishing type and equipment (e.g., spin fishing, fly fishing, flat fishing, etc.), fishing boat characteristics (e.g., boat 
size, fuel cost, dockage, etc.) and harvested fish types (e.g., peacock bass, large-mouth bass, seatrouts, snapper, tarpons, sharks, tuna, etc.).

Here is the formal representation of the empirical model used to estimate the market price of fishing trips as a hedonic function of trip characteristics (linear model; equation 3.1):

$P=p_{0}+\sum_{i} \tau_{i} T_{i}+\sum_{j} \eta_{i} E_{j}+\sum_{k} \beta_{k} B_{k}+\sum_{l} \phi_{l} F_{l}+\varepsilon_{P}$

where $T_{i}, E_{j}, B_{k}$, and $F_{l}$ respectively denote the $i^{\text {th }}$ trip parameter, $j^{\text {th }}$ fishing and equipment type, $k^{\text {th }}$ boat parameter, and $l^{\text {th }}$ harvested fish type. The values $\tau_{i}, \eta_{j}, \beta_{k}$, and $\phi_{i}$ represent the coefficients of each of the features and can be obtained by running a regression model on the actual market prices of different fishing trips (dependent variable, $P$ ) and their characteristics (explanatory variables, $T, E, B, F$ ). The parameters $p_{0}$ and $\varepsilon_{P}$ specify the constant coefficient of the trip price and the error term of the hedonic price function respectively (Taylor, 2003).

In case the linear model indicates a large and significant error value, a more sophisticated hedonic price function can be deployed in the form of semi-log or doublelog models or even a hybrid model which combines different functional forms. The semilog, double-log and the hybrid models are represented as follows (equations 3.2, 3.3, and 3.4) (Taylor, 2003):

Semi-log model: $\ln P=p_{0}+\sum_{i} \tau_{i} T_{i}+\sum_{j} \eta_{i} E_{j}+\sum_{k} \beta_{k} B_{k}+\sum_{l} \phi_{l} F_{l}+\varepsilon \mathrm{P}$,

Double-log model: $\ln P=p_{0}+\sum_{i} \tau_{\mathrm{i}} \ln T_{i}+\sum_{j} \eta_{\mathrm{j}} \ln E_{j}+\sum_{k} \beta_{\mathrm{k}} \ln B_{k}+\varepsilon \mathrm{p}$,

Hybrid model: $\ln P=p_{0}+\sum_{i} \tau_{\mathrm{i}} T_{i}+\sum_{j} \eta_{\mathrm{j}} \ln E_{j}+\sum_{k} \beta_{\mathrm{k}} B_{k}+\sum_{l} \phi_{l} F_{l}+\varepsilon_{P}$. 
As mentioned before, the objective is to find the implicit price for each trip characteristic which quantifies the contribution of each feature to the total fishing trip price. The implicit (marginal) price of an arbitrary characteristic $z$ is defined as $\partial P / \partial z$. For example, the implicit price of parameter $T_{i}$ in the hybrid model is equal to $\tau_{i} \cdot P_{m}$ where $P_{m}$ denotes the median of the input market prices. In the same hybrid model, the marginal price of parameter $E_{j}$ is computed as $\eta_{j} \cdot P_{m} / \hat{E}_{j}$ where $\hat{E}_{j}$ is the best constant estimation (median or mean value) of the parameter $E_{j}$. After calculating the implicit price for each characteristic, the relative effect of each trip characteristic on the total price provides us a better understanding of the anglers' economic preferences for these recreational fishing trips offered by guides and outfitters.

\section{B. Economic Impact Analysis}

As mentioned earlier, economic impact analysis is a common way to know the monetary influences of the trades between customers and suppliers (like manufacturing sectors) in an economy. Usually, it estimates the variations in industry income, industry profits, personal salaries, and jobs. An economic impact analysis usually estimates the variation in economic actions between two cases. In one case, we suppose that an event happens, while in another case, we suppose it does not happen. The IMPLAN (IMpact analysis for PLANning) is a widely used software for input-output analysis. The U.S. Department of Agriculture and Forest Service (DAFS, 1979) initially developed IMPLAN software (Poudel, 2014).

By using IMPLAN software, we are able to quantify the economic impact of recreational fishing in Florida. In order to evaluate the economic impact of recreational 
fishing offered by guides and outfitters, we develop the IMPLAN model by using 2008 IMPLAN data and implicit prices from our hedonic price analysis. In order to quantify the direct, indirect, induced, and total effects of expenditures on recreational fishing offered by guides and outfitters, we need to evaluate the main economic indicators including employment, total income, personal income, total output, and value-added (in millions of dollars) (Poudel, 2014). Values are stated in 2016 dollars and are inflated from 2008 dollars by a scale of 1.11 using the Bureau of Labor Statistics Consumer Price Index Inflation Calculator (Savolainen et al., 2014).

\section{Data Collection}

First, we collect the list of more than 200 guides' and outfitters' websites from the Florida Fish and Wildlife Conservation Commission during May and July of 2015. For this research, an outfitter or guide is an entity which has access to different freshwater and saltwater fishing opportunities and can offer fishing trip packages. The data are gathered from the websites through which outfitters and guides offer different fishing trip packages. We need to consider three factors when we use the online price information specified by outfitters and guides. First, the price on the website indicates the on-site retail price (Pitts et al., 2012). Brynjolfsson and Smith (2000) and Little and Berrens (2008) studied the comparison of in-store price and Internet price and they showed that there is no major difference. In order to make sure that the prices of fishing trip packages are the same as the in-store prices, we called more than $10 \%$ of guides and outfitters and they confirmed that there is no major difference between online and in-store prices. Also, it is assumed that each trip implies at-least one sale (Pitts et al., 2012). The last issue is 
that we consider each trip package as an unweighted observation in terms of trip duration. It means that a fishing trip package is considered as one observation regardless of how long the offered fishing trip is; e.g. a day-long trip and a multi-day trip are both considered as single observations (Pitts et al., 2012).

We have collected data regarding the details of fishing trip packages that the guides and outfitters offer to their customers. The total number of compiled fishing trip packages that guides and outfitters currently offer in Florida is more than 3150. Among them, 650 packages are offered by outfitters, while the others are offered by guides. About $39.7 \%$ of the packages offer freshwater fishing trips and the remaining $60.3 \%$ of packages offer saltwater fishing trips ( $71 \%$ of saltwater trips offer inshore fishing, while $29 \%$ of them provide offshore/nearshore fishing).

Table 7 describes the dependent and independent variables used in the HP analysis. The dependent variable is the price for freshwater or saltwater fishing trips led by guides and outfitters. The extra trips per package variable is one of the independent variables, and represents the number of extra trips in a fishing package offered by guides/outfitters. Obviously, this variable is zero if the package offers one fishing trip. The concept of multi-trip fishing packages is similar to bulk purchasing when the guides/outfitters will accept a slightly lower sales price for each trip, if the angler will agree to purchase multiple trips. 
Table 7: Definition of the Variables Used in the Proposed Model

\begin{tabular}{|c|c|c|}
\hline \multicolumn{2}{|l|}{ Variables } & Definition \\
\hline \multicolumn{2}{|c|}{ Price (USD) } & Price of a fishing trip offered by guides and outfitters \\
\hline \multicolumn{2}{|c|}{ Fuel cost (US Dollar) } & Cost of the fuel burned by the fishing boat during a trip \\
\hline \multicolumn{2}{|c|}{ Extra trips per package } & Number of extra trips in a multi-trip package (zero otherwise) \\
\hline \multicolumn{2}{|c|}{ Duration (Hour) } & Duration of a fishing trip \\
\hline \multicolumn{2}{|c|}{ Number of Anglers } & Number of anglers allowed in a fishing trip package \\
\hline \multicolumn{2}{|l|}{ Boat size } & If the boat size is greater than the median size; yes $=1, \mathrm{no}=0$ \\
\hline \multicolumn{2}{|l|}{ Lodging } & Accommodation and food provided in the trip; yes $=1, \mathrm{no}=0$ \\
\hline \multicolumn{2}{|c|}{ Freshwater } & If the type of fishing trip is freshwater; yes $=1, \mathrm{no}=0$ \\
\hline \multicolumn{2}{|l|}{ Inshore } & If the fishing destination is inshore, yes $=1$, no $=1$ \\
\hline \multicolumn{2}{|c|}{ Outfitter-led Trip } & If the fishing trip is led and sold by an outfitter; yes $=1$, no= 0 \\
\hline \multirow{5}{*}{$\begin{array}{l}\text { Freshwater } \\
\text { Species }\end{array}$} & Largemouth & Fish species is largemouth bass; yes $=1$, no $=0$ \\
\hline & Peacock & Freshwater fish species is peacock bass; yes $=1$, no $=0$ \\
\hline & Crappie & Freshwater fish species is crappie; yes $=1, \mathrm{no}=0$ \\
\hline & Bluegill & Freshwater fish species is bluegill; yes $=1$, no $=0$ \\
\hline & Gar & Freshwater fish species is gar; yes $=1, \mathrm{no}=0$ \\
\hline \multirow{11}{*}{$\begin{array}{l}\text { Saltwater } \\
\text { Species }\end{array}$} & Redfish & Saltwater fish species is redfish; yes $=1$, no $=0$ \\
\hline & Tarpons & Saltwater fish species is tarpons; yes $=1, \mathrm{no}=0$ \\
\hline & Snooks & Saltwater fish species is snooks; yes $=1$, no $=0$ \\
\hline & Seatrouts & Saltwater fish species is seatrouts; yes $=1, \mathrm{no}=0$ \\
\hline & Snappers & Saltwater fish species is a snapper; yes $=1, \mathrm{no}=0$ \\
\hline & Sharks & Saltwater fish species is a sharks; yes $=1, \mathrm{no}=0$ \\
\hline & Dolphin & Saltwater fish species is dolphin; yes $=1, \mathrm{no}=0$ \\
\hline & Tuna & Saltwater fish species is tuna; yes $=1$, no $=0$ \\
\hline & Groupers & Saltwater fish species is a groupers; yes $=1, \mathrm{no}=0$ \\
\hline & Sailfish & Saltwater fish species is sailfish; yes $=1, \mathrm{no}=0$ \\
\hline & Flounder & Saltwater fish species is flounder; yes $=1, \mathrm{no}=0$ \\
\hline \multirow{3}{*}{$\begin{array}{l}\text { Area of } \\
\text { Operation }\end{array}$} & Statewide & The area of operation for fishing trips is statewide $=1$ \\
\hline & Regional & The area of operation for fishing trips is regional= 1 \\
\hline & Countywide & The area of operation for fishing trips is county $=1$ \\
\hline
\end{tabular}


The next variable is duration which is based on number of hours (i.e., 4, 6, 8) respectively half, $3 / 4$, and full day fishing trips. The number of anglers is another independent variable which can affect the total fishing trip price. There are data for the allowed maximum number of anglers on the websites and it means that the fishing trip price is fixed for the allowed number of anglers. Usually, if the customers want to bring more than the allowed number of anglers, they should pay an extra fee which depends on the duration of the trip and ranges from $\$ 50$ to $\$ 100$. We created this variable based on the number of additional anglers since the price differs when the packages have more than the allowed number of anglers. Usually for inshore saltwater and freshwater fishing trips, the extra number of anglers is not mentioned, because the boat is not large enough to accept additional anglers.

Also, boat size is one of those fishing trip characteristics that can influence the fishing trip price. The larger the boat, the more anglers can be accommodated and thus it can change the price. Because those offering saltwater and freshwater fishing trips in Florida require a gas boat, so the fuel cost is another factor which affects the price.

Moreover, there are some trip characteristics that are represented by 0/1 dummy ${ }^{6}$ variables. Variables food and lodging are commonly offered in multi-day fishing trips or offshore/nearshore trips. Also, the type of fishing trip (i.e., saltwater or freshwater fishing trips) can affect the price as the equipment, size of boat, duration, and the targeted fish species are different with saltwater fishing trips compared to freshwater fishing trips. Similarly, the inshore dummy variable can change the price of a fishing trip since the

\footnotetext{
${ }^{6}$ In statistics, particularly in regression analysis, a dummy variable is one that takes the value 0 or 1 to indicate the absence or presence of some categorical effect that may be expected to shift the outcome.
} 
price of offshore fishing trips are higher than inshore fishing trips due to differences in associated fishing trip characteristics. Saltwater and freshwater fish species can also influence the price, since some of the fish species are popular for catch and release or some fish species are difficult to catch (like sharks or sailfish). Also, the equipment that is required to catch a specific fish species may influence the price of a fishing trip packages. The area of operation is one of the characteristics that we are interested in knowing its impact on the price. In order to specify a guide's area of operation, we define three dummy variables statewide, regional, and county.

After cleaning and processing the collected data, we classify the packages into three different categories: freshwater (FW) fishing, saltwater inshore (SWI) and saltwater offshore (SWO) fishing. After building the model using statistics tools (STATA and R software), we can analyze the impact of different fishing trip characteristics on the price of the trip and can estimate the implicit price for every variable included in the fishing trip model. We use Tobit regression to calculate the coefficients of the proposed hedonic model. For each of the aforementioned categories, we also take corresponding fish types into consideration. For example, we use the variable largemouth as an independent variable. The variation in trip prices due to other fish types are also considered in the same way.

We then employ IMPLAN-2008 to estimate the economic impacts of recreational fishing (led by fishing guides and outfitters) on the economy at the state, regional, and county levels. To do so, we utilize the computed implicit prices of participating variables in the hedonic model to estimate the guides' and outfitters' expenditures. Table 8 
describes the industry sectors which are mostly affected by the recreational fishing trips and pre-defined in the IMPLAN-2008 software.

We model the recreational fishing trips as a number of scenarios with each scenario in a specific Florida county where guides and/or outfitters are located. In each scenario, we considered three activities (freshwater, saltwater inshore, and saltwater offshore fishing) of type "industry change" including sale events in the following industrial sectors: "Other Amusement and Recreation Industries" (IMPLAN Code 410), "Transport by Water" (IMPLAN Code: 334), "Retails - Gasoline Stations" (IMPLAN Code 326), "Insurance Carriers" (IMPLAN Code 357), etc. (See Table 8).

Table 8: List of the Most Influential Industry Sectors in Recreational Charter Fishing

\begin{tabular}{l|l|}
$\begin{array}{l}\text { Sector } \\
\text { Code }\end{array}$ & Description \\
\hline 410 & Other amusement and recreation industries \\
\hline 326 & Retail Stores - Gasoline stations \\
\hline 334 & Transport by Water \\
\hline 357 & Insurance Carriers \\
\hline 413 & Food services and drinking places \\
\hline 382 & Employment services \\
\hline 319 & Wholesale trade businesses \\
\hline
\end{tabular}


CHAPTER IV. RESULTS

\section{A. Descriptive Statistics of Recreational Trip Database}

This section focuses on the descriptive statistics of our collected data regarding the fishing trip packages offered by the guides and outfitters in Florida. As mentioned in Chapter III, we categorize the total number of 3191 packages into three classes: freshwater (FW), saltwater inshore (SWI), and saltwater offshore (SWO) fishing trips. The data depicted in Figure 1 shows how the packages are distributed among these three classes. The red column in this figure shows the classification of packages sold by guides, while the blue one depicts how the outfitter-led fishing packages are divided into the three mentioned classes.

The primary difference between an outfitter and guide is that an outfitter is sort of a one-stop-shop in the sense that they usually take care of all aspects of a trip (including lodging, meals, trips, etc.); however, a guide tends to focus on specific tasks and fish species (i.e., bonefish expert, marlin fishing, etc.). In Florida most of the outfitter-type businesses are involved in hunting or in fishing. Some areas where that is not the case are in the Western US or in the Alaska charter fishing market, where the fishing guides work through outfitters (C. Phillips, personal communication, October 6, 2015). According to Figure 1, almost $80 \%$ of the fishing trips are provided by guides and the rest of the trips are provided by outfitters. Moreover, the majority of the freshwater, saltwater inshore, and saltwater offshore fishing trips are offered by guides (87\%, 74\% and 78\% respectively). 
Number of Fishing Trip Packages

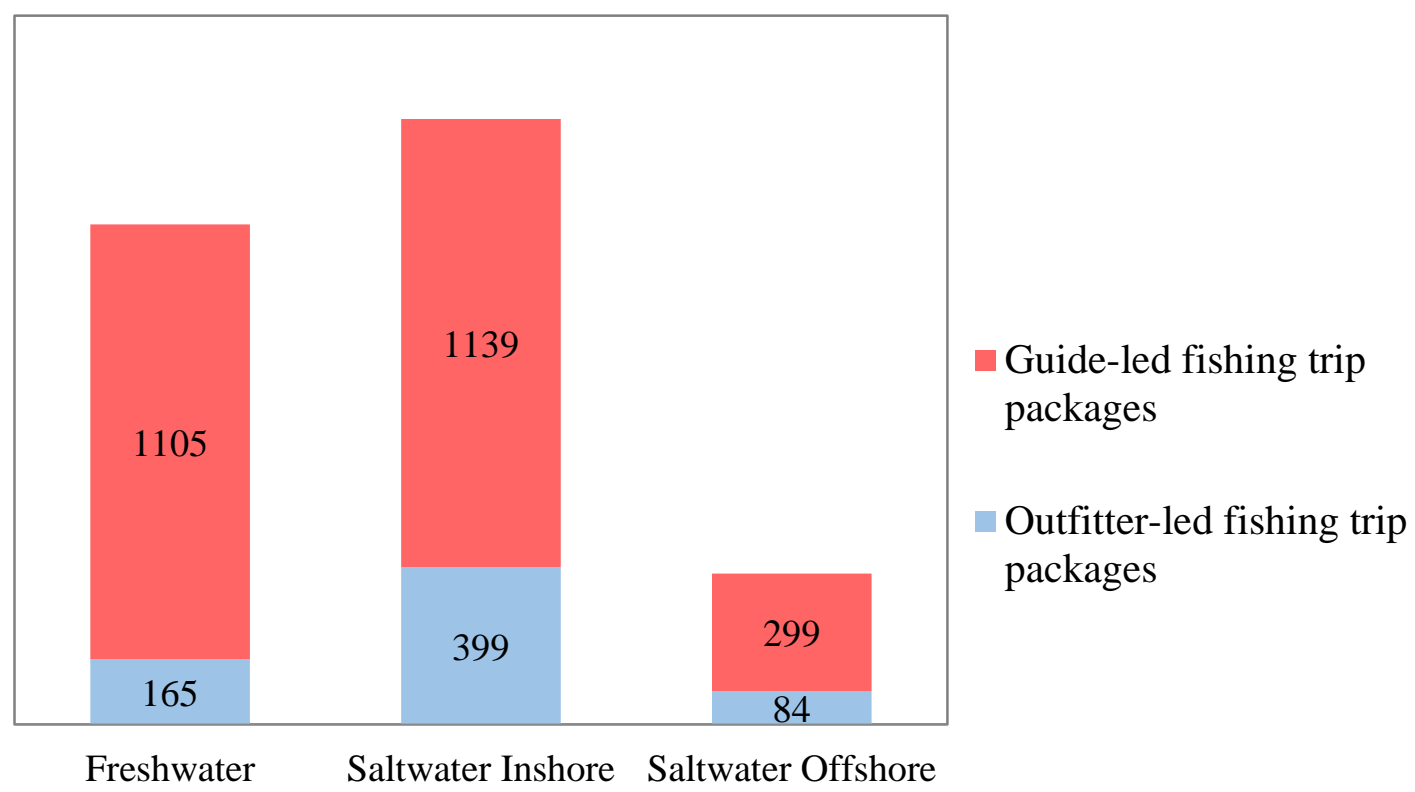

Figure 1: Column Chart of Recreational Charter Fishing Based on the Seller and Fishing Type

Additionally, Figure 2 classifies the packages into three categories based on the distance of the fishing spot from the shoreline: inshore (if distance is less than 1 miles), offshore (if distance is greater than 10 miles), and near-shore (if distance is from 1 to 10 miles) fishing trips. Based on Figure 2, 82\% of total fishing trips are offered for inshore fishing trips by both guides and outfitters (freshwater and saltwater inshore), and the rest of the fishing trips provide nearshore and offshore trip packages (6\% and $12 \%$ respectively).

Table 9 and Table 10 provide descriptive statistics of how the proposed model variables (described in Table 7) are distributed. Table 10 specifies the mean and standard deviation of the dummy variables; while Table 9 provides the quintiles of the nondummy variables along with their means and standard deviations. According to Table 9 
the mean of price, price/person and price/hour are \$683.5, \$182.1, and \$101.3 respectively. Also, the mean of fuel cost as a non-dummy variable is $\$ 75.65$. Additionally, based on Table 10, only 6.24\% of guides and outfitters provide lodging and food. Also, more than $60 \%$ of the fishing trips are saltwater fishing trips and more than $80 \%$ of them are inshore fishing trips. The distribution of the area of operation shows that the area of operation of more than $50 \%$ of the fishing trips is regional. Furthermore, Table 10 shows that $26 \%$ of total fishing trips offer largemouth bass as a freshwater fish species and more than $34 \%$ of the saltwater inshore fishing trips offer redfish.

$$
\text { - Inshore Trips } \quad \text { Nearshore Trips } \quad \text { Offshore Trips }
$$

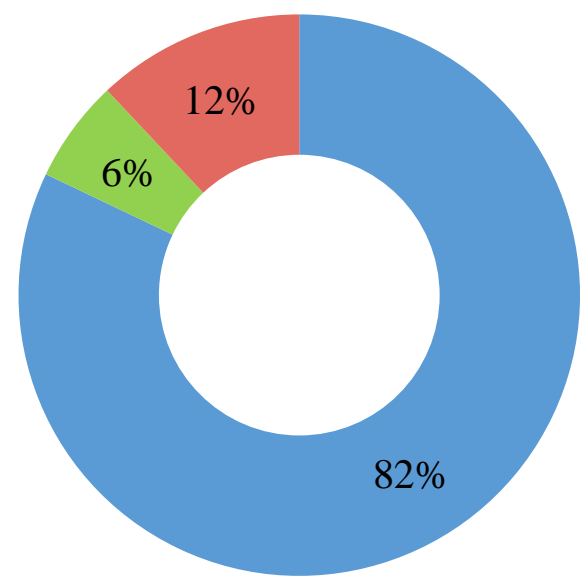

Figure 2: Doughnut Chart of Inshore, Nearshore, and Offshore Fishing Trip Packages

In order to gain a better understanding of the dependent variable of our proposed model, we depict the distribution of trip price and trip price per person per hour in Figure 3 and Figure 4. As these plots illustrate, the price of trips sold by outfitters are distributed in a slightly wider range than the price of those offered by guides. Based on Figure 3 and 
Table 9, the price as the dependent variable is right skewed with standard deviation of \$1054.3. Also, Figure 3 indicates that more than $90 \%$ of fishing trip packages offered by guides and outfitters are sold at the price of $\$ 800$ or less. Additionally, Figure 4 shows that the trip price per person per hour is less than $\$ 25$ for more than half of the packages offered by guides. However, less than $40 \%$ of the packages offered by outfitters are cheaper than \$25 per person per hour. Additionally, Figure 5 compares the price distribution based on the type of fishing trips. As depicted in Figure 5, the price of more than half of the freshwater fishing trips cost less than $\$ 400$, while less than $30 \%$ (15\%) of the saltwater inshore (offshore) fishing trips are cheaper than $\$ 400$.

Table 9: Descriptive Statistics of the Trip Characteristics Variables.

\begin{tabular}{|l|l|l|l|l|l|l|l|}
\hline Variable & Mean & $\begin{array}{l}\text { Std. } \\
\text { Dev. }\end{array}$ & Min & $\begin{array}{l}\text { First } \\
\text { Quantile }\end{array}$ & Median & $\begin{array}{l}\text { Third } \\
\text { Quantile }\end{array}$ & Max \\
\hline Price (\$) & 683.5 & 1054.3 & 75.0 & 375.0 & 475.0 & 600.0 & 12,000 \\
\hline Fuel Cost (\$) & 75.65 & 203.98 & 0 & 30.60 & 37.51 & 45.13 & 2994 \\
\hline Duration (Hour) & 6.7 & 4.5 & 2.0 & 4.0 & 6.0 & 8.0 & 72 \\
\hline Number of Anglers & 3.7 & 3.8 & 1.0 & 2.0 & 3.0 & 4.0 & 24 \\
\hline Extra Trips/Pkg - & 0.091 & 0.391 & 0 & 0 & 0 & 0 & 2 \\
\hline Price/Person & 182.1 & 104.1 & 20.8 & 125.0 & 162.5 & 201.7 & 1,500 \\
\hline Price/Hour & 101.3 & 102.8 & 16.0 & 62.5 & 81.3 & 100.0 & 1,500 \\
\hline Price/Person/Hour & 28.8 & 10.7 & 5.2 & 21.3 & 26.7 & 34.4 & 100 \\
\hline
\end{tabular}


Table 10: Descriptive Statistics of the Dummy Variables Attributes

\begin{tabular}{|c|c|c|c|c|}
\hline \multicolumn{2}{|c|}{ Dummy Variables (X) } & $X=1$ & $\mathrm{X}=\mathbf{0}$ & STD \\
\hline \multicolumn{2}{|l|}{ Lodging } & $6.24 \%$ & $93.76 \%$ & $24.19 \%$ \\
\hline \multicolumn{2}{|c|}{ Freshwater Trip } & $39.80 \%$ & $60.20 \%$ & $48.96 \%$ \\
\hline \multicolumn{2}{|l|}{ Inshore Trip } & $82.14 \%$ & $17.86 \%$ & $38.31 \%$ \\
\hline \multicolumn{2}{|c|}{ Outfitter-led Trips } & $20.31 \%$ & $79.69 \%$ & $40.23 \%$ \\
\hline \multicolumn{2}{|l|}{ Boat Size } & $50 \%$ & $50 \%$ & $50 \%$ \\
\hline \multirow{5}{*}{ FW Species } & Largemouth & $26.23 \%$ & $73.77 \%$ & $44.00 \%$ \\
\hline & Peacock & $8.56 \%$ & $91.44 \%$ & $27.97 \%$ \\
\hline & Crappie & $8.05 \%$ & $91.95 \%$ & $27.22 \%$ \\
\hline & Bluegill & $2.82 \%$ & $97.18 \%$ & $16.56 \%$ \\
\hline & Gar & $2.63 \%$ & $97.37 \%$ & $16.01 \%$ \\
\hline \multirow{17}{*}{ SW Species } & Redfish & $34.79 \%$ & $65.21 \%$ & $47.64 \%$ \\
\hline & Tarpons & $30.77 \%$ & $69.23 \%$ & $46.16 \%$ \\
\hline & Snooks & $30.08 \%$ & $69.92 \%$ & $45.87 \%$ \\
\hline & Seatrouts & $30.49 \%$ & $69.51 \%$ & $46.04 \%$ \\
\hline & Snapper & $15.10 \%$ & $84.90 \%$ & $35.82 \%$ \\
\hline & Wahoo & $4.95 \%$ & $95.05 \%$ & $21.70 \%$ \\
\hline & Cobia & $10.18 \%$ & $89.82 \%$ & $30.25 \%$ \\
\hline & Sharks & $19.02 \%$ & $80.98 \%$ & $39.25 \%$ \\
\hline & Dolphin & $7.18 \%$ & $92.82 \%$ & $25.81 \%$ \\
\hline & Tuna & $6.05 \%$ & $93.95 \%$ & $23.84 \%$ \\
\hline & Groupers & $11.00 \%$ & $89.00 \%$ & $31.29 \%$ \\
\hline & Swordfish & $0.38 \%$ & $99.62 \%$ & $6.12 \%$ \\
\hline & Sailfish & $5.11 \%$ & $94.89 \%$ & $22.02 \%$ \\
\hline & Jack & $6.64 \%$ & $93.36 \%$ & $24.91 \%$ \\
\hline & Flounder & $1.47 \%$ & $98.53 \%$ & $12.05 \%$ \\
\hline & Tripletail & $1.60 \%$ & $98.40 \%$ & $12.54 \%$ \\
\hline & King Mackerel & $15.86 \%$ & $84.14 \%$ & $36.53 \%$ \\
\hline \multirow{3}{*}{$\begin{array}{l}\text { Area of } \\
\text { Operation }\end{array}$} & Statewide & $5.73 \%$ & $94.27 \%$ & $23.25 \%$ \\
\hline & Regional & $58.10 \%$ & $41.90 \%$ & $49.35 \%$ \\
\hline & Countywide & $31.62 \%$ & $68.38 \%$ & $48.06 \%$ \\
\hline
\end{tabular}




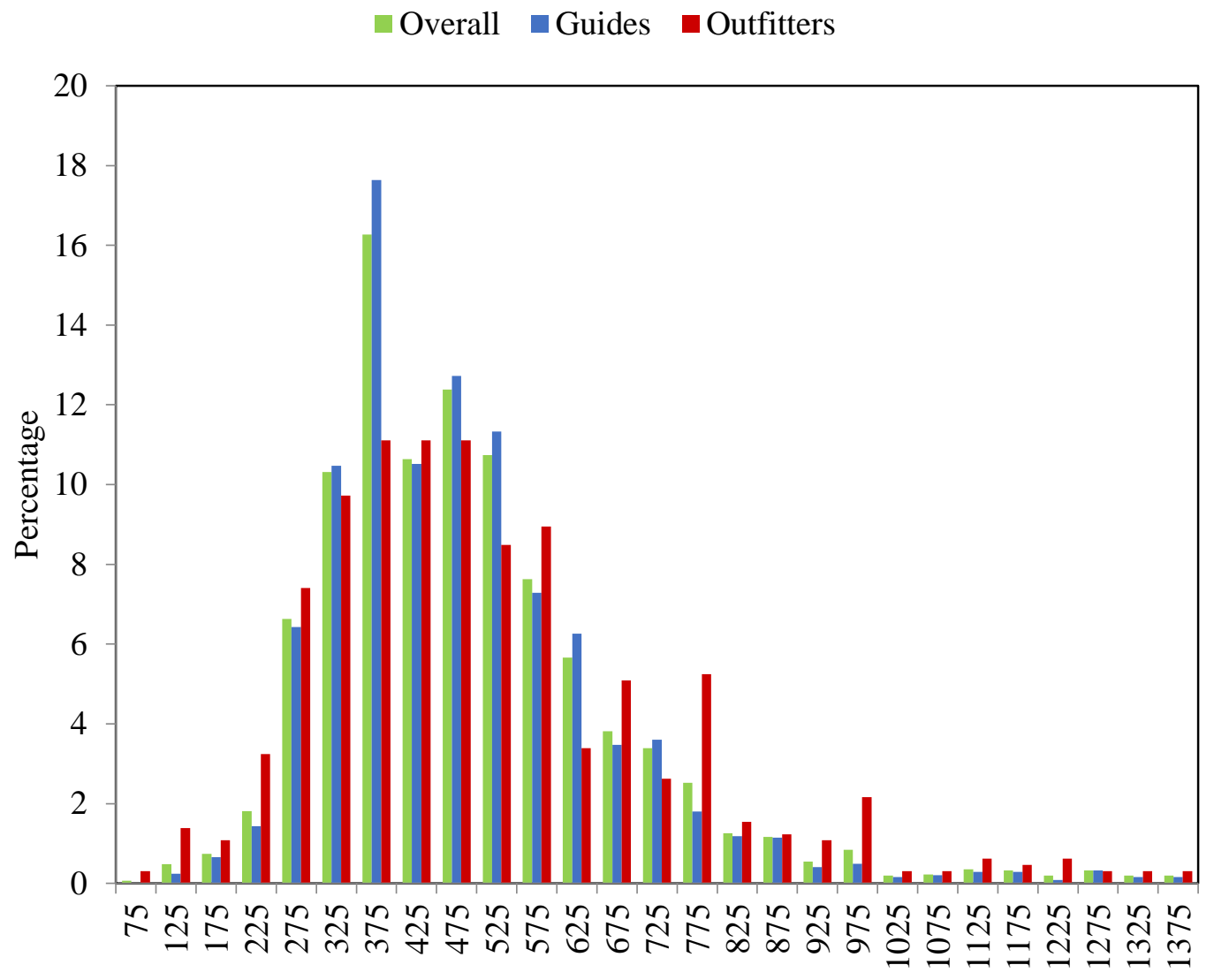

Trip Price (\$)

Figure 3: Distribution Plots of Trip Prices

\section{B. Hedonic Model Estimation}

This section builds the hedonic price model for trip prices offered by guides and outfitters in Florida. As mentioned before, the fishing trip packages are categorized into three classes: freshwater, saltwater inshore and saltwater offshore fishing trips. As Figure 5 shows, trip price is differently distributed across these three classes. Additionally, some of the variables defined in Table 7 do not affect the trip price in a specific class. For example, the dummy variable largemouth determines whether largemouth bass fish is intended to be caught on a freshwater fishing trip or not. Since largemouth bass is a 
freshwater fish, the variable largemouth likely does not have any effect on saltwater trip price. Henceforth, we build a separate hedonic model for each of the three aforementioned classes. As mentioned in Chapter III, in order to estimate a hedonic model for recreational fishing trip price, we use semi-log models and Tobit regression analysis. Based on Taylor's (2003) study, in case of unobservable dominant variables or errors, semi log or double log hedonic models are more precise.

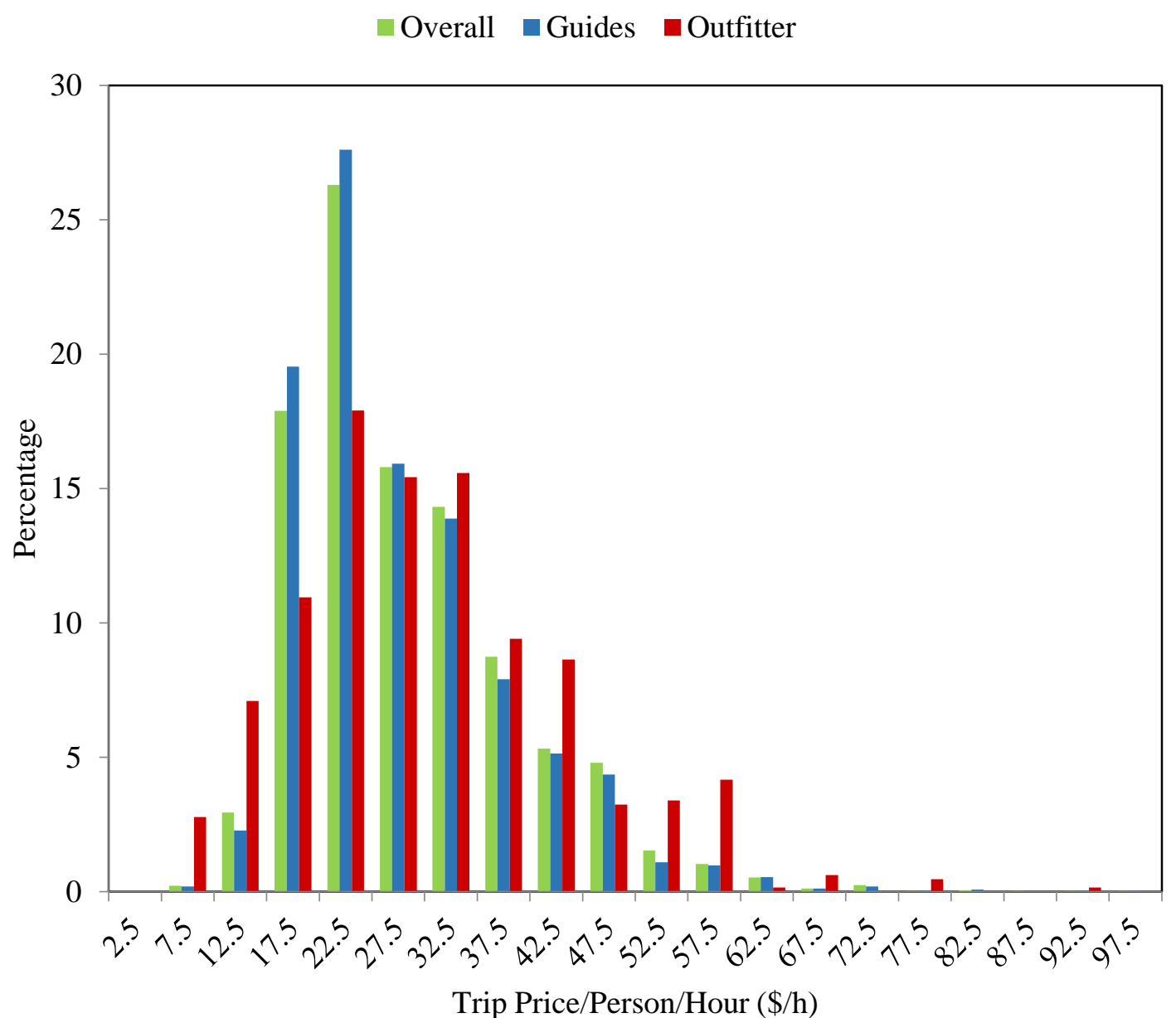

Figure 4: Distribution Plots of Trip Price per Person per Hour 


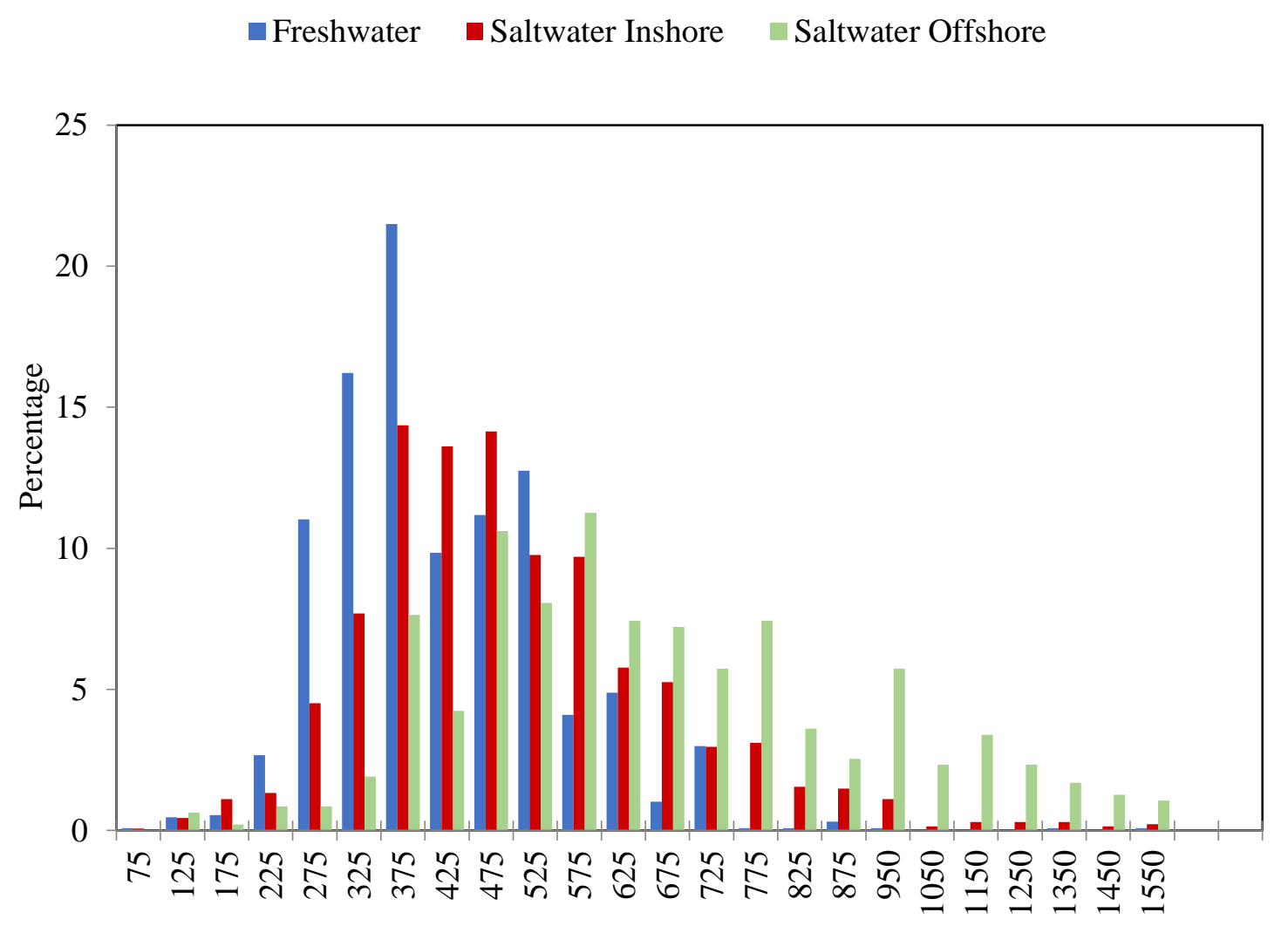

Trip Price (\$)

Figure 5: Comparison of Price Distribution for Freshwater, Saltwater Inshore and Saltwater Offshore Trips for Recreational Fishing in Florida.

\section{B.1. Freshwater Recreational Fishing Model Construction}

Table 11 shows the model constructed for freshwater fishing trip prices in column three. We construct the model in which most of the participating independent variables are highly statistically significant. In this model, the p-value corresponding to the variable fuel cost shows that this variable is highly significant with positive sign indicating that fuel cost variable has a positive effect on the price of the freshwater fishing trip. Moreover, based on the freshwater model, extra trips/package is statistically significant at $1 \%$ level (-0.092) indicating a negative effect on the price. This negative effect can be 
interpreted that if a trip package has an extra trip option, based on bulk purchasing; guides/outfitters accept a slightly lower price for the trip.

Furthermore, numbers of anglers, duration as non-dummy variables are statistically significant at $1 \%$ level with the expected positive signs. It means that by increasing the number of anglers and duration, fishing trip prices will increase. The next variable that is statistically significant is lodging with positive sign. The sign indicates that the lodging option will increase the price of a fishing trip package. However, the statistically significant outfitter and statewide variables can influence on the price negatively. Perhaps, anglers do not consider outfitter and statewide as their favorite fishing trip characteristics. Finally, fishing trip species including crappie, peacock, bluegill and gar are statistically significant with negative sign. The negative sign could show anglers' preferences of their most regular habitats (Pitts et al., 2012). It means that the anglers may not put too much value for these fish species when choosing fishing trip packages.

\section{B.2. Saltwater Inshore Recreational Fishing Model Construction}

Table 11 shows the model constructed for saltwater inshore fishing trip packages in column four. We build a hedonic model containing the largest possible set of independent variables for the saltwater inshore fishing trip packages. We obtain our model in Table 11 in which most of the independent variables are highly statistically significant at the $95 \%$ confidence level. 
Table 11: Semi-Log Hedonic Models for Freshwater, Saltwater Inshore, and Saltwater Offshore Fishing Trip Prices

\begin{tabular}{|c|c|c|c|c|c|}
\hline \multirow{2}{*}{\multicolumn{2}{|c|}{ Variable Name }} & \multirow[b]{2}{*}{ Var } & \multicolumn{3}{|c|}{ Coefficients and Standard Deviation } \\
\hline & & & Freshwater & Saltwater Inshore & $\begin{array}{l}\text { Saltwater } \\
\text { Offshore }\end{array}$ \\
\hline \multicolumn{2}{|l|}{ Fuel Cost } & $v_{0}$ & $0.003 * * *(0.001)$ & $0.002 * *(0.001)$ & $0.001^{* * *}(0)$ \\
\hline \multicolumn{2}{|c|}{ Extra Trips/Pkg. } & $v_{1}$ & $-0.092 * * *(0.016)$ & $-0.066(0.047)$ & -- \\
\hline \multicolumn{2}{|c|}{ Num. of Anglers } & $v_{2}$ & $0.133^{* * *}(0.005)$ & $0.065^{* * *}(0.004)$ & $0.011 * * *(0.003)$ \\
\hline \multicolumn{2}{|c|}{ Duration } & $v_{3}$ & $0.074 * * *(0.002)$ & $0.089 * * *(0.003)$ & -- \\
\hline \multicolumn{2}{|l|}{ Lodging } & $v_{4}$ & $0.287 * * *(0.027)$ & $0.044(0.046)$ & $0.476^{* *}(0.227)$ \\
\hline \multicolumn{2}{|l|}{ Outfitter } & $v_{5}$ & $-0.049 * *(0.02)$ & $0.006(0.014)$ & $-0.01(0.044)$ \\
\hline \multicolumn{2}{|l|}{ Statewide } & $v_{6}$ & $-0.131 * * *(0.018)$ & $-0.163^{* * *}(0.031)$ & $-0.444 * * *(0.101)$ \\
\hline \multicolumn{2}{|l|}{ Boat Size } & $v_{7}$ & $-0.004(0.003)$ & $0.012 * * *(0.003)$ & $0.035 * * *(0.003)$ \\
\hline \multirow{5}{*}{$\begin{array}{l}\text { FW } \\
\text { Species }\end{array}$} & Largemouth & $v_{8}$ & $-0.017(0.013)$ & -- & -- \\
\hline & Peacock & $v_{9}$ & $-0.034 * *(0.015)$ & -- & -- \\
\hline & Crappie & $v_{10}$ & $-0.05^{* * * *}(0.013)$ & -- & -- \\
\hline & Bluegill & $v_{11}$ & $-0.046 * *(0.019)$ & -- & -- \\
\hline & Gar & $v_{12}$ & $-0.068 * * *(0.021)$ & -- & -- \\
\hline \multirow{5}{*}{$\begin{array}{l}\text { SW } \\
\text { Inshore } \\
\text { Species }\end{array}$} & Redfish & $v_{13}$ & -- & $-0.046 * *(0.02)$ & -- \\
\hline & Tarpons & $v_{14}$ & -- & $0.078^{* * *}(0.012)$ & -- \\
\hline & Snooks & $v_{15}$ & -- & $-0.007(0.015)$ & -- \\
\hline & Seatrouts & $v_{16}$ & -- & $-0.095 * * *(0.016)$ & -- \\
\hline & Snapper & $v_{17}$ & -- & $0.016(0.015)$ & -- \\
\hline \multirow{5}{*}{$\begin{array}{l}\text { SW } \\
\text { Offshore } \\
\text { Species }\end{array}$} & Cobia & $v_{18}$ & -- & -- & $0.004(0.051)$ \\
\hline & Sharks & $v_{19}$ & -- & -- & $-0.162 * * *(0.038)$ \\
\hline & Groupers & $v_{20}$ & -- & -- & $-0.115 * * *(0.043)$ \\
\hline & Dolphin & $v_{21}$ & -- & -- & $0.145^{* * *}(0.05)$ \\
\hline & Mackerel & $v_{22}$ & -- & -- & $0.043(0.036)$ \\
\hline \multicolumn{3}{|c|}{ Constant Value } & $5.058 * * *(0.027)$ & $5.386 * * *(0.028)$ & $6.156 * * *(0.044)$ \\
\hline \multirow{2}{*}{\multicolumn{3}{|c|}{ Standard Deviation }} & $0.0165(0.003)$ & $0.212(0.004)$ & $0.429(0.013)$ \\
\hline & & & $\begin{array}{c}\mathrm{LR} \chi^{2}(12)=554 \\
\operatorname{Pr} .>\chi^{2}=0.000 \\
L L V=-244.5\end{array}$ & $\begin{array}{c}\mathrm{LR} \chi^{2}(11)=530 \\
\operatorname{Pr} .>\chi^{2}=0.000 \\
L L V=-256.7\end{array}$ & $\begin{array}{c}\mathrm{LR} \chi^{2}(10)=536 \\
\operatorname{Pr} .>\chi^{2}=0.00 \\
L L V=-258.7\end{array}$ \\
\hline
\end{tabular}

$* * *, * *, *$ imply significance at 1, 5 and $10 \%$ levels, respectively; numbers in parentheses are corresponding standard error 
Based on the saltwater inshore fishing model, fuel cost, duration, number of anglers and boat size as independent variables are statistically significant with the expected positive sign, meaning that if the fuel cost, number of anglers, boat size, and duration of a trip increase, the price of the saltwater inshore fishing trip will increase as well. Moreover, statewide variable is statistically significant at $1 \%$ level with negative impact on the price respectively. Also, saltwater inshore fish species including redfish, tarpons, seatrouts are statistically significant. Tarpons variable has a positive effect on the price while seatrouts and redfish have a negative impact on the price.

\section{B.3. Saltwater Offshore Recreational Fishing Model Construction}

Table 11 indicates the semi-log model constructed for saltwater offshore fishing trip packages. We build a hedonic semi-log model in which most of the variables are statistically significant at the $95 \%$ confidence level. According to the saltwater offshore semi-log model, fuel cost, number of anglers and boat size variables are statistically significant at $1 \%$ level with expected positive impact on the price of the trip. Moreover, statewide variable is statistically significant at $1 \%$ level with negative sign which affects the price negatively. Among the saltwater offshore fish species variables, sharks and groupers are statistically significant with negative sign; however, dolphin variable is significant and affects the price positively.

\section{B.4. Final Estimated Hedonic Model}

By considering the three models in Table 11, we obtain Equation (4.1) that determines the price of a trip as a function of the aforementioned independent variables. The first part of this equation considers the semi-log Hedonic model when the packages 
offer freshwater fishing trips. As you see, the variable coefficients are obtained from Table 11. Additionally, the formula computes the price of a saltwater inshore trip in Table 11. In the third part of the formula, the price of saltwater offshore trips is calculated utilizing the saltwater offshore model in Table 11.

$$
\text { Price }=\left\{\begin{array}{cc}
157.28 e^{0.003 v_{0}} \times e^{-0.092 v_{1}} \times e^{0.133 v_{2}} & \\
\times e^{0.074 v_{3}} \times e^{0.287 v_{4}} \times e^{-0.049 v_{5}} \times & \text { If } \mathrm{FW}=1 \\
e^{-0.131 v_{6}} \times e^{-0.034 v_{9}} \times e^{-0.05 v_{10}} & \\
e^{-0.046 v_{11}} \times e^{-0.068 v_{12}} & \\
218.36 e^{0.002 v_{0}} \times e^{0.065 v_{2}} \times e^{0.089 v_{3}} & \\
\times e^{-0.163 v_{6}} \times e^{0.012 v_{7}} \times e^{-0.046 v_{13}} \times & \text { If FW =0 \& Inshore = 1 } \\
e^{0.078 v_{14}} \times e^{-0.095 v_{16}} & \\
471.68 e^{0.001 v_{0}} \times e^{0.011 v_{2}} \times e^{0.476 v_{4}} \times & \\
e^{-0.444 v_{6}} \times e^{0.035 v_{7}} \times e^{-0.162 v_{19}} \times & \text { Otherwise } \\
e^{-0.115 v_{20}} \times e^{0.145 v_{21}} &
\end{array}\right.
$$

\section{B.5. Implicit Price Estimation}

As mentioned in Chapter III, the effect of each independent variable (included in the hedonic model) on the value of the dependent variable (trip price) constitutes the implicit price of fishing trip attribute represented by that independent variable. By definition, implicit price, or equivalently marginal price, of an independent variable like $z$ is defined as the partial derivative of the dependent variable with respect to the variable $z$. Since our proposed model in the previous section is a combination of three hedonic models (freshwater, saltwater inshore, and saltwater offshore) and some variables are included in more than one model, there can be multiple implicit prices for a specific variable. Table 12 shows the implicit price of each variable (if available) in each of the three fishing trip categories. 
Table 12: Implicit Price Estimation

\begin{tabular}{|c|c|c|c|c|c|}
\hline \multirow{2}{*}{\multicolumn{2}{|c|}{ Variable Name }} & \multirow[b]{2}{*}{ Var. } & \multicolumn{3}{|c|}{ Implicit Price (Marginal Impact) } \\
\hline & & & Freshwater & $\begin{array}{l}\text { Saltwater } \\
\text { Inshore }\end{array}$ & $\begin{array}{l}\text { Saltwater } \\
\text { Offshore }\end{array}$ \\
\hline \multicolumn{2}{|l|}{ Fuel Cost } & $v_{0}$ & 1.38 & 1.01 & 1.08 \\
\hline \multicolumn{2}{|c|}{ Extra Trips/Pkg } & $v_{1}$ & -36.63 & -32.99 & -- \\
\hline \multicolumn{2}{|c|}{ Num. of Anglers } & $v_{2}$ & 53.27 & 32.39 & 17.4 \\
\hline \multicolumn{2}{|l|}{ Duration } & $v_{3}$ & 29.51 & 44.33 & -- \\
\hline \multicolumn{2}{|l|}{ Lodging } & $v_{4}$ & 132.96 & -- & 962.5 \\
\hline \multicolumn{2}{|l|}{ Outfitter } & $v_{5}$ & -19.26 & -- & -- \\
\hline \multicolumn{2}{|c|}{ Statewide } & $v_{6}$ & -49.21 & -75.06 & -565.49 \\
\hline \multicolumn{2}{|l|}{ Boat Size } & $v_{7}$ & -- & 6.16 & 56.82 \\
\hline \multirow{5}{*}{$\begin{array}{l}\text { FW } \\
\text { Species }\end{array}$} & Largemouth & $v_{8}$ & -- & -- & -- \\
\hline & Peacock & $v_{9}$ & -13.36 & -- & -- \\
\hline & Crappie & $v_{10}$ & -19.48 & -- & -- \\
\hline & Bluegill & $v_{11}$ & -18.01 & -- & -- \\
\hline & Gar & $v_{12}$ & -26.31 & -- & -- \\
\hline \multirow{5}{*}{$\begin{array}{l}\text { SW } \\
\text { Inshore } \\
\text { Species }\end{array}$} & Redfish & $v_{13}$ & -- & -22.42 & -- \\
\hline & Tarpons & $v_{14}$ & -- & 40.53 & -- \\
\hline & Snooks & $v_{15}$ & -- & -- & -- \\
\hline & Seatrouts & $v_{16}$ & -- & -45.3 & -- \\
\hline & Snapper & $v_{17}$ & -- & -- & -- \\
\hline \multirow{5}{*}{$\begin{array}{l}\text { SW } \\
\text { Offshore } \\
\text { Species }\end{array}$} & Cobia & $v_{18}$ & -- & -- & -- \\
\hline & Sharks & $v_{19}$ & -- & -- & -235.33 \\
\hline & Groupers & $v_{20}$ & -- & -- & -171.79 \\
\hline & Dolphin & $v_{21}$ & -- & -- & 246.96 \\
\hline & King Mackerel & $v_{22}$ & -- & -- & -- \\
\hline
\end{tabular}


Since our proposed model in previous section is semi-log, the implicit price of a non-dummy variable is obtained by multiplying its corresponding coefficient by the median of the dependent variable. Here is a step-by-step calculation of the implicit price of a non-dummy variable like $v_{3}$ (duration) where $P$ represents the trip price as the dependent variable of the model:

$$
\ln P=c_{3} v_{3}+\sum_{i \neq 3} c_{i} v_{i} \rightarrow \frac{\partial P}{\partial v_{3}} \times \frac{1}{P}=c_{3} \rightarrow \frac{\partial P}{\partial v_{3}}=P \times c_{3}
$$

Consequently, a constant estimation of the implicit price of $v_{3}$ is equal to $\widehat{P} \times c_{3}$ where $\hat{P}$ is the median of price.

In contrast, the implicit price of a dummy variable like $v_{4}$ (lodging) is obtained by a different approach as the dependent variable is not derivable with respect to a dummy variable. Here is a step-by-step calculation of the marginal effect of the variable $v_{4}$ on the dependent variable (let $P_{0}$ and $P_{1}$ denote the values of the dependent variable when the dummy variable $v_{4}$ is equal to 0 and 1 respectively):

$$
\begin{aligned}
& \ln P=c_{4} v_{4}+\sum_{i \neq 4} c_{i} v_{i} \rightarrow P=e^{c_{4} v_{4}} \times \exp \left(\sum_{i \neq 4} c_{i} v_{i}\right) \\
& \rightarrow \frac{\Delta P}{\Delta v_{4}}=\frac{P_{1}-P_{0}}{1-0}=\left(e^{c_{4}}-1\right) \exp \left(\sum_{i \neq 4} c_{i} v_{i}\right)=\left(e^{c_{4}}-1\right) P_{0} .
\end{aligned}
$$

Subsequently, implicit price of the dummy variable $v_{4}$ is equal to $\left(e^{c_{4}}-1\right) \widehat{P_{0}}$ where $\widehat{P_{0}}$ is the median of the dependent variable when $v_{4}=0$ (Halvorsen \& Palmquist, 1980).

As Table 12 depicts, the implicit prices of different independent variables based on the types of fishing trips (freshwater, saltwater inshore, and saltwater offshore) are 
estimated. The implicit price of fuel cost in freshwater, saltwater inshore and saltwater offshore fishing trips is estimated as 1.38, 1.01, and 1.08 respectively. The implicit price of fuel cost in freshwater fishing trip is equal to 1.38 which means that for every dollar spent on fuel by guides/outfitters in each freshwater trip, $\$ 1.38$ will be added to the price of the trip. Likewise, in saltwater inshore and saltwater offshore fishing trips, for every dollar spent on fuel by guides/outfitters, $\$ 1.01$ and $\$ 1.08$ will be added to the price of the saltwater inshore and saltwater offshore fishing trips respectively.

Based on Table 12, marginal effects of other non-dummy variables in the freshwater fishing trips including extra trips per package, number of anglers, and duration are estimated as \$-36.63, \$53.27 and \$29.51 correspondingly. These estimated implicit prices indicate that by increasing extra trips per package, number of anglers and duration in freshwater fishing trips, the price of the trips will be decreased \$-36.63 and increased \$53.27 and \$29.51 in average respectively. Also, marginal effects of dummy variables including lodging, outfitter, and statewide in freshwater, saltwater inshore, and saltwater offshore fishing trips are estimated as well (See Table 12). For instance, the marginal prices of dummy variables including lodging, outfitter, and statewide in freshwater fishing trips calculated as \$132.96, \$-19.26, and \$-49.21 on average respectively. The negative signs of the variables outfitter and statewide may reveal that the price of the freshwater fishing trip which has an outfitter or a statewide option, is reduced by \$-75.06 and \$-49.21 respectively. Moreover, freshwater and saltwater fish species including peacock, crappie, bluegill, gar, redfish, seatrouts, sharks and groupers 
have negative effect on the price of the fishing trips. However, tarpons and dolphin with implicit prices of $\$ 40.53$ and $\$ 246.96$ have negative impact on the saltwater fishing trips.

\section{Economic Impact Analysis (EIA)}

As mentioned in Chapter III, we use IMPLAN in order to compute the economic impacts of recreational fishing (led by fishing guides and outfitters) on Florida's economy at the regional and county levels. Table 8 shows a number of industry sectors chosen from the 440 pre-defined sectors in the IMPLAN software. These sectors are the ones that are most affected by recreational fishing. We considered three "industry change” activities related to recreational fishing: freshwater, saltwater inshore and saltwater offshore fishing. As Table 13 shows, each activity includes a number of sale events in the following industrial sectors: "Other Amusement and Recreation Industries" (IMPLAN Code 410), "Transport by Water" (IMPLAN Code: 334), "Retails - Gasoline Stations" (IMPLAN Code 326), "Insurance Carriers" (IMPLAN Code 357), etc. Then, we use the online information provided by Florida Fish and Wildlife Conservation Commission (FFWCC, 2016c) and the implicit price of the lodging and fuel cost variables in Table 12 in order to find the amount of industry change for each sector. Obviously, each "industry change” activity needs to be scaled up by the number of fishing trips (of a specific kind) offered by the guides and outfitters in a specific county. By simulating the aforementioned scenario in IMPLAN-2008, we estimate the economic impacts of recreational fishing on different industry sectors in Florida. The summary of our results is shown in Table 14. 
Table 13: List of Charter Fishing Expenses and Their Associated IMPLAN Sectors

\begin{tabular}{|l|l|l|l|l|l|}
\hline Expenses & IMPLAN Sector & $\begin{array}{l}\text { Sector } \\
\text { Code }\end{array}$ & $\begin{array}{l}\text { FW } \\
\text { Fishing }\end{array}$ & $\begin{array}{l}\text { SW } \\
\text { Inshore } \\
\text { Fishing }\end{array}$ & $\begin{array}{l}\text { SW } \\
\text { Offshore } \\
\text { Fishing }\end{array}$ \\
\hline Fuel Cost & Retail gas stations & 326 & $1,140,519$ & $6,526,982$ & $1,864,239$ \\
\hline Lodging & Hotels and motels & 411 & 498,136 & 238,001 & 93,363 \\
\hline $\begin{array}{l}\text { Licenses and } \\
\text { Permits }\end{array}$ & $\begin{array}{l}\text { State and local } \\
\text { government, non- } \\
\text { education }\end{array}$ & 437 & 76,270 & 195,840 & 71,632 \\
\hline $\begin{array}{l}\text { Insurance } \\
\text { Insurance carriers }\end{array}$ & 357 & 789,000 & $1,728,000$ & 363,000 \\
\hline $\begin{array}{l}\text { Transport by water } \\
\text { Dockage }\end{array}$ & 334 & 315,600 & $1,036,800$ & 290,400 \\
\hline $\begin{array}{l}\text { Wages and } \\
\text { Other } \\
\text { Expenses }\end{array}$ & $\begin{array}{l}\text { Other amusement } \\
\text { and recreation } \\
\text { industries }\end{array}$ & 410 & $8,798,737$ & $34,740,887$ & $33,275,029$ \\
\hline
\end{tabular}

As you see in Table 14, the impact of saltwater and freshwater fishing on the top eight industry sectors has been specified separately. The third column of Table 14 specifies how many people get employed every year in each of these sectors. Columns four, five, and six of Table 14 specify the labor income, value added, and total output in each sector caused by recreational fishing in the State of Florida. Based on Table 14 “Other amusement and recreation industries” sector by generating more than 450 jobs and making $\$ 76.98$ million in total output has the highest economic impact by recreational charter fishing in Florida. However “The wholesale trade businesses” sector by creating 14.5 jobs and making $\$ 2.78$ million in total output has been affected the least by recreational charter fishing in the first eight industry sectors shown in Table 14. 
Table 14: Top Eight Industry Sectors Affected by Recreational Charter Fishing in Florida

\begin{tabular}{|c|c|c|c|c|c|}
\hline & & Employment & $\begin{array}{l}\text { Labor } \\
\text { Income } \\
\text { (million \$) }\end{array}$ & $\begin{array}{l}\text { Value } \\
\text { Added } \\
\text { (million \$) }\end{array}$ & $\begin{array}{l}\text { Total } \\
\text { Output } \\
\text { (million \$) }\end{array}$ \\
\hline \multirow{3}{*}{$\begin{array}{l}\text { 410-Other } \\
\text { Amusements }\end{array}$} & Total & 453.4 & 16.64 & 29.25 & 76.98 \\
\hline & FW & 52 & 1.91 & 3.35 & 8.82 \\
\hline & SW & 401.5 & 14.74 & 25.9 & 68.16 \\
\hline \multirow{3}{*}{$\begin{array}{l}\text { 360-Real estate } \\
\text { establishment }\end{array}$} & Total & 40 & 1.08 & 5.17 & 7.38 \\
\hline & FW & 4.8 & 0.13 & 0.62 & 0.89 \\
\hline & SW & 35.2 & 0.95 & 4.55 & 6.49 \\
\hline \multirow{3}{*}{$\begin{array}{l}\text { 382-Employment } \\
\text { Services }\end{array}$} & Total & 32.5 & 0.85 & 0.92 & 1.38 \\
\hline & FW & 4 & 0.1 & 0.11 & 0.17 \\
\hline & SW & 28.5 & 0.75 & 0.81 & 1.21 \\
\hline \multirow{3}{*}{$\begin{array}{l}\text { 413-Food services } \\
\text { \& drinking places }\end{array}$} & Total & 31.1 & 0.8 & 1.17 & 2.41 \\
\hline & FW & 3.9 & 0.1 & 0.15 & 0.3 \\
\hline & SW & 27.2 & 0.7 & 1.02 & 2.1 \\
\hline \multirow{3}{*}{$\begin{array}{l}\text { 357-Insurance } \\
\text { carriers }\end{array}$} & Total & 16.1 & 1.29 & 2.38 & 6.51 \\
\hline & FW & 3.1 & 0.25 & 0.46 & 1.25 \\
\hline & SW & 13 & 1.05 & 1.92 & 5.26 \\
\hline \multirow{3}{*}{$\begin{array}{l}\text { 388-Services to } \\
\text { buildings \& } \\
\text { dwellings }\end{array}$} & Total & 15.5 & 0.42 & 0.52 & 1.08 \\
\hline & FW & 1.9 & 0.05 & 0.06 & 0.13 \\
\hline & SW & 13.6 & 0.37 & 0.46 & 0.95 \\
\hline \multirow{3}{*}{$\begin{array}{l}\text { 326-Retail store, } \\
\text { gas station }\end{array}$} & Total & 15.5 & 0.51 & 1.18 & 1.76 \\
\hline & FW & 1.9 & 0.06 & 0.14 & 0.21 \\
\hline & SW & 13.6 & 0.45 & 1.04 & 1.55 \\
\hline \multirow{3}{*}{$\begin{array}{l}\text { 319-Wholesale } \\
\text { trade businesses }\end{array}$} & Total & 14.5 & 1.18 & 2.04 & 2.78 \\
\hline & FW & 1.8 & 0.14 & 0.25 & 0.34 \\
\hline & SW & 12.8 & 1.04 & 1.79 & 2.44 \\
\hline
\end{tabular}


Moreover, as Table 15 depicts, the fishing expenditures were classified into two categories: freshwater and saltwater fishing expenditures. Based on Table 15, the total economic impact of freshwater charter fishing trips and saltwater charter fishing trips are estimated separately. The total impacts of freshwater charter fishing have generated 114.9 jobs and have made \$ 19.07 million as total output. However, the total economic impact of saltwater fishing trip is more than freshwater charters' impact by creating more than 807 jobs and making an economic output of \$132.12 million in 2015.

Based on Table 15, the direct economic impact of recreational charter fishing is estimated as creating 482.6 jobs (including part-time and full time jobs), making $\$ 18.17$ million as salaries and wages, and $\$ 84.07$ million as total output. Moreover, the total direct impacts of Florida charter fishing have created indirect and induced impacts on employment, income, and total output. The indirect and induced impacts of total (both saltwater and freshwater) recreational charter fishing on employment generated 253.1 and 186.7 jobs respectively.

Furthermore, the total economic impact (sum of direct, indirect, and induced impacts) of fishing led by guides and outfitters created 922.4 full time and part time jobs, made \$39.5 million as salaries and wages, and generated \$151.19 million as total output. The last row of Table 15 shows the economic impacts of West Florida charter fishing conducted by Savolainen et al. (2014). Based on their results, West Florida charter fishing generated an economic output of \$119.89 million, labor income of \$42.6 million, and 911 jobs in 2014. By comparing our results with the results of Savolainen et al. (2014), it can be concluded that the economic impact of recreational charter fishing in 
making jobs and total output in our study is more than the results of Savolainen et al. (2014).

Table 15: Detailed Comparison of Economic Impact Analysis of Florida Recreational Charter Fishing Based on Our Results in 2015 with the Results of Savolainen et al. (2014).

\begin{tabular}{|c|c|c|c|c|c|}
\hline & $\begin{array}{l}\text { Impact } \\
\text { Type }\end{array}$ & Employment & $\begin{array}{l}\text { Labor } \\
\text { Income } \\
\text { (million \$) }\end{array}$ & $\begin{array}{l}\text { Value } \\
\text { Added } \\
\text { (million \$) }\end{array}$ & $\begin{array}{l}\text { Total } \\
\text { Output } \\
\text { (million \$) }\end{array}$ \\
\hline \multirow{4}{*}{$\begin{array}{l}\text { Florida Charter } \\
\text { Freshwater Fishing } \\
\text { (our results, 2015) }\end{array}$} & Direct & 59.8 & 2.33 & 4.15 & 10.66 \\
\hline & Indirect & 31.4 & 1.61 & 2.7 & 4.98 \\
\hline & Induced & 23.7 & 1.08 & 1.99 & 3.42 \\
\hline & Total & 114.9 & 5.02 & 8.84 & 19.07 \\
\hline \multirow{4}{*}{$\begin{array}{l}\text { Florida Charter } \\
\text { Saltwater Fishing } \\
\text { (our results, 2015) }\end{array}$} & Direct & 422.8 & 15.85 & 28.16 & 73.41 \\
\hline & Indirect & 221.7 & 11.23 & 19.07 & 35.18 \\
\hline & Induced & 163.0 & 7.4 & 13.66 & 23.53 \\
\hline & Total & 807.5 & 34.48 & 60.89 & 132.12 \\
\hline \multirow{4}{*}{$\begin{array}{l}\text { Florida Charter } \\
\text { Fishing } \\
\text { Total } \\
\text { (our results, 2015) }\end{array}$} & Direct & 482.6 & 18.17 & 32.31 & 84.07 \\
\hline & Indirect & 253.1 & 12.85 & 21.77 & 40.17 \\
\hline & Induced & 186.7 & 8.48 & 15.65 & 26.95 \\
\hline & Total & 922.4 & 39.5 & 69.73 & 151.19 \\
\hline \multirow{4}{*}{$\begin{array}{l}\text { West FL } \\
\text { Charter Fishing } \\
\text { (Results of } \\
\text { Savolainen et al., } \\
\text { 2014) }\end{array}$} & Direct & 138.00 & 5.80 & -- & 15.59 \\
\hline & Indirect & 48.00 & 2.39 & -- & 7.31 \\
\hline & Induced & 724.00 & 34.40 & -- & 97.00 \\
\hline & Total & 911.00 & 42.60 & -- & 119.89 \\
\hline
\end{tabular}


Also, by estimating direct, indirect and induced impacts, we are able to evaluate the Social Accounting Matrix (SAM) multipliers for every economic impact characteristic (Minnesota IMPLAN Group, 2009). The SAM gives a better understanding of the economic transactions taken place between different economic sectors of a region or state in a specific fiscal year. Based on Table 16, the SAM multipliers of freshwater and saltwater fishing for employment are 1.92 and 1.91 respectively. These numbers imply that for every 100 jobs created as the direct impact of freshwater fishing expenditures, 92 more jobs are indirectly created through its indirect/induced impact; however, saltwater fishing has indirectly created 91 jobs when its direct impact has created 100 new jobs. Thus, freshwater fishing had a lager employment multiplier (1.92) than saltwater employment multiplier (1.91) in Florida. Nevertheless, the total income and total output multipliers of saltwater fishing were larger than those of freshwater fishing.

Table 16: Social Accounting Matrix (SAM) Multipliers for Fishing Expenditures of Florida Recreational Fisheries.

\begin{tabular}{|l|l|l|l|l|} 
& $\begin{array}{l}\text { Employment } \\
\text { Multiplier }\end{array}$ & $\begin{array}{l}\text { Labor Income } \\
\text { Multiplier }\end{array}$ & $\begin{array}{l}\text { Total output } \\
\text { Multiplier }\end{array}$ & $\begin{array}{l}\text { Value Added } \\
\text { Multiplier }\end{array}$ \\
\hline $\begin{array}{l}\text { Florida } \\
\text { Freshwater Fishing }\end{array}$ & 1.92 & 2.16 & 2.13 & 1.79 \\
\hline $\begin{array}{l}\text { Florida } \\
\text { Saltwater Fishing }\end{array}$ & 1.91 & 2.18 & 2.16 & 1.8 \\
\hline $\begin{array}{l}\text { Florida } \\
\text { Total }\end{array}$ & 1.9 & 2.2 & 2.2 & 1.8 \\
\hline
\end{tabular}




\section{CHAPTER V. DISCUSSION AND CONCLUSION}

To calculate the coefficients of our hedonic functions, we used three semi-log hedonic models. We ran a Tobit regression models for each freshwater fishing trip, saltwater inshore fishing trip, and saltwater offshore fishing trip. Findings from these

models have some implications that are worth highlighting. Table 11 specifies the results of the Tobit models applied to freshwater, saltwater inshore and saltwater offshore fishing trips. In the freshwater fishing model, some of the independent variables like extra trips per package have negative coefficients (i.e., increasing the extra trip/package will result in reducing the price). The concept of offering extra trips in a package is similar to bulk purchasing as guides/outfitters accept a slightly lower price for each trip, if the angler agrees to purchase multiple trips.

Additionally, in freshwater, saltwater inshore, and saltwater offshore models, the coefficient of number of anglers is positive and statistically significant which indicates that if a fishing trip takes an hour longer; the anglers are willing to pay more for the fishing trip package. Similarly, the lodging variable in freshwater fishing model is statistically significant and has $\$ 132.96$ as an implicit price (see Table 12 ), meaning that if a freshwater fishing trip package has a lodging option; the customers are willing to pay $\$ 132.96$ more for the trip. The coefficient of the lodging variable related to saltwater inshore fishing trips, is not significant. The reason might be that few inshore saltwater fishing trip packages have the lodging option. 
Additionally, the coefficients of freshwater fish species including peacock, crappie, bluegill, and gar have negative sign and are statistically significant. Perhaps, the anglers value these freshwater fish species less than other fish species. Likewise, in saltwater inshore and saltwater offshore models, variables redfish, seatrouts, sharks, and groupers representing the saltwater fish species are statistically significant and have negative effect on the price, implying that the anglers consider less value for them comparing to other saltwater fish species. The results of the implicit prices for freshwater, saltwater inshore and saltwater offshore semi-log models are shown in Table 12. According to Table 12, the implicit price of duration in freshwater model is $\$ 29.51$ per hour. While, the variable duration has the marginal implicit price of $\$ 44.33$ per hour in the category of saltwater inshore fishing trips.

As Table 12 shows, the variable number of anglers has a marginal price of \$53.27 per angler on the price of the freshwater fishing trip. However, this variable has a lower implicit price in saltwater fishing trips. The lowest implicit price of number of anglers happens in saltwater offshore fishing trips where a boat usually carries more anglers in comparison with other types of fishing trips. As a result, incrementing the number of anglers in a saltwater offshore fishing trip would only increase the trip price by less than $\$ 18$ which is almost one third of the estimated implicit price of number of anglers in a freshwater fishing trip.

Moreover, the implicit price of lodging has a marginal impact of $\$ 132.96$ on the price of a freshwater fishing trip. However, the implicit price of lodging on the price of saltwater offshore fishing trips is $\$ 962.5$ which is more than the implicit price of 
freshwater fishing trips. The reason is that the saltwater offshore fishing trips usually take longer than freshwater fishing trips and the anglers consider the lodging option more necessary in saltwater offshore fishing trips. In addition, the variable outfitter has the marginal effect of \$-19.26 on the price of freshwater fishing trips. The negative marginal effect of the variable outfitter in the freshwater model may reflect that anglers are more interested in having freshwater fishing trips with guides rather than with outfitters. Similarly, the variable statewide decreases the value of freshwater, saltwater inshore and saltwater offshore fishing trips. It may reveal that anglers prefer to have a charter fishing trip with countywide or regional guides and outfitters.

Also, we estimated the marginal value of different fish species. The variables crappie, peacock, blue gill, and gar have the estimated marginal impacts of \$-19.48, \$13.36, \$-18.01 and \$-26.31 respectively on the price of the freshwater fishing trips. As Table 12 shows, the implicit prices of all the freshwater fish species are negative. However, it doesn't mean that every freshwater fish species decreases the trip price as every package offers at-least one fish type and the fish type with the least negative implicit price would have the most positive impact on the freshwater fishing trip price. In this case, gar has the most negative marginal impact on the price. Also, the anglers prefer peacock fish to the crappie as the implicit price of variable peacock is greater than crappie.

Furthermore, the variables redfish and seatrouts decrease the value of saltwater inshore fishing trips; while, tarpons adds more value to the saltwater inshore fishing trips. Likewise sharks and groupers reduce the price of an offshore fishing trip, while dolphin 
makes the saltwater fishing trips more valuable. The positive marginal effect of variables, tarpons and dolphin may reveal their rarity, while the negative implicit price of redfish, seatrouts, sharks, and groupers may reflect anglers' values of their most common habitats (Pitts et al., 2012).

In addition, we estimated the economic impacts of recreational charter fishing on Florida's economy. First, we chose the associated industry sectors from the 440 predefined sectors in the IMPLAN software. These selected sectors have the most impact on the Florida recreational charter fishing market. Based on Table 14, the impact of saltwater and freshwater charter fishing on every sector has been specified separately. The sector “other amusements” by making the labor income and total output of $\$ 16.64$ and $\$ 76.98$ million respectively has the most effect by the recreational charter fishing market in Florida. However, the sector of "wholesale trade businesses" has the lowest impact by generating 14 jobs and making $\$ 2.78$ million as total output.

This study presented a different method to estimate the value of recreational fishing trips using online data from guides and outfitters in Florida. In this research, we used the HP analysis to analyze the variations in the prices offered by the guides and outfitters. We constructed 3 different models (i.e., 1 model for freshwater, 1 model for saltwater inshore, and 1 model for saltwater offshore fishing trips) of the hedonic function using Tobit regression. After running the regressions, we estimated the values (implicit prices) for a variety of characteristics of freshwater and saltwater fishing trips led by guides and outfitters. Then, we used 2008 IMPLAN data, implicit prices of our hedonic price analysis and the online information provided by Florida Fish and Wildlife 
Conservation Commission (FFWCC, 2016c) to estimate the economic impacts of recreational charter fishing in Florida. The results can be used by state and national policymakers for their future policy design.

Recreational fishing guides and outfitters in Florida with high potential fishing sites can improve the economy of Florida in county and regional levels by attracting more tourists. The non-resident fishermen who wish to go angling for multiple days need accommodation and related services. However, the results show that only $6.2 \%$ of Florida guides and outfitters offer lodging and food and only $9.1 \%$ of them provide extra fishing trips per package. It is recommended to develop policies that facilitate the attraction of more non-resident anglers. 


\section{REFERENCES}

Adamowicz, W. L. (1994). Habitat Formation and Variety Seeking in a Discrete Choice Model of Recreation Demand. Journal of Agricultural and Resource Economics, 19(1), 19-31.

Agnello, R. (1989). The Economic Value of Fishing Success: An Application of Socioeconomic Survey Data. Fishery Bulletin, 87(l), 223-232.

American Sportfishing Association (ASA). (2013). An Economic Force for Conservation. Alexandria, VA: American Sportfishing Association.

Bell, F. W., and Leeworthy, V. R. (1990). Recreational Demand by Tourists for Saltwater Beach Days. Journal of Environmental Economics and Management, 18(3), 189-205.

Bell, F. W., Sorensen, P. E., and Leeworthy, V. R. (1982). The Economic Impact and Valuation of Saltwater Recreational Fisheries in Florida (Report No. R/FR-16). Miami, FL: Florida Sea Grant College.

Berrens, R. P., Bergland, O., and Adams, R. M. (1993). Valuation Issues in an Urban Recreational Fishery: Spring Chinook Salmon in Portland, Oregon. Journal of Leisure Research, 25(1), 70-83.

Bockstael, N. E., McConnell, K. E., and Strand, I. (1989). A Random Utility Model for Sportfishing: Some Preliminary Results for Florida. Marine Resource Economics, 6(3), 245-260.

Brynjolfsson, E., and Smith, M. D. (2000). Frictionless Commerce? A Comparison of Internet and Conventional Retailers. Management Science, 46(4), 563-585.

Carter, D. W., Agar, J. J., and Waters, J. R. (2008). Economic Framework for Fishery Allocation Decisions with an Application to Gulf of Mexico Red Groupers. Miami, FL: NOAA Technical Memorandum, NMFS-SEFSC-576.

Coleman, F. C., Figueira, W. F., Ueland, J. S., and Crowder, L. B. (2004). The Impact of United States Recreational Fisheries on Marine Fish Populations. Science, 305(5692), 1958-1960.

Cooke, S.J., and Cowx, I.G. (2006). Contrasting Recreational and Commercial Fishing: Searching for Common Issues to Promote Unified Conservation of Fisheries Resources and Aquatic Environments. Biological Conservation, 128(2006), 93-108.

Cutlac, M., and Weber, M. (2014). The Economic Impact of Outfitted Hunting in Alberta. Alberta, Canada: Innovates Technology Futures. Retrieved from 
http://www.apos.ab.ca/media/13785/the-economic-impact-of-outfitted-hunting-inalberta.pdf

Elde, L., Seid, A., and Gorma, B. (2008). Sports Fishing's Economic Impact on the Bethel Census Area. Retrieved from https://uaf.edu/files/ces/ruraldevelopment/publications/SportsFishing.pdf

Englin, J., and Shonkwiler. J. S. (1995). Modeling Recreation Demand in the Presence of Unobservable Travel Costs toward a Travel Price Model. Journal of Environmental Economics and Management, 29(3), 368-77.

Fedler, A. J., \& Hayes, C. (2007). Economic Impact of Recreational Fishing for Bonefish, Permit and Tarpons in Belize. Retrieved from http://www.nautilusreels.com/app/webroot/userfiles/66/bpt\%20economic\%20report\%20\%20final2.pdf

Fedler, T. (2010). The Economic Impact of Flats Fishing in the Bahamas. The Bahamas National Bonefish and Tarpons Trust. Retrieved from https://www.igfa.org/images/uploads/files/Bahamas_Flats_Economic_Impact_Report.pdf

Florida Fish and Wildlife Conservation Commission (FFWCC). (2016a, January16). Fishing Capital of the World. Retrieved from http://myfwc.com/fishing/freshwater/black-bass/background/fishing-capital/

Florida Fish and Wildlife Conservation Commission (FFWCC). (2016b, January 16). Saltwater shoreline fishing, License Requirement. Retrieved from http://myfwc.com/license/recreational/saltwater-fishing/shoreline-faqs/

Florida Fish and Wildlife Conservation Commission (FFWCC). (2016c, January 16). Recreational Fisheries Landings. Retrieved from http://myfwc.com/research/saltwater/fishstats/recreational-fisheries/landings/

Freeman, A. M. (1993). The Measurement of Environmental and Resource Values: Theory and Methods. Washington, D.C.: Resources for the Future.

Graeven, R. (2013). Report on Contingent Valuation: An Alternative Method to Value Recreational Fishing and the Fishing Resource. Retrieved from http://sites.miis.edu/raineygraeven/2013/07/17/angling-and-contingentvaluation/\#sthash.0QBerHCC.dpuf

Halvorsen, H., and Palmquist, R. (1980). The interpretation of dummy variables in semilogarithmic equations. The American Economic Review, 70(3), 474-475.

Hamel, C., Herrmann, M., Lee, S. T., and Criddle, K. R. (2000). An Economic Assessment of the Sport Fisheries for Halibut, and Chinook and Coho Salmon in 
Lowerand Central Cook Inlet. Corvallis, Oregon: International Institute for Fisheries Economics and Trade. Retrieved from http://www.boem.gov/BOEMNewsroom/Library/Publications/2000/2000_061.aspx

Hodges, A., Mulkey, D., Philippakos, E., and Adams, C. (2002). Economic Impact of Florida's Commercial Fisheries and Aquaculture Industries. Institute of Food and Agricultural Sciences. Retrieved from http://nsgl.gso.uri.edu/flsgp/flsgpg01011.pdf

Hotelling, H. (1947). Letter to the National Park Service, Reprinted in An Economic Study of the Monetary Evaluation of Recreation in the National Parks (1949). Washington, DC: U.S. Department of the Interior, National Park Service and Recreational Planning Division.

Hussain, A., Munn, I. A., Grado, S. C., and Henderson, J. E. (2008). Economic Impacts of Mississippi Wildlife-Associated Outfitters and their Clientele. Human Dimensions of Wildlife, 13(4), 243-251.

Ihde, T. F., Wilberg, M. J., Loewensteiner, D. A., Secor, D.H., and Miller, T. J. (2011). The Increasing Importance of Marine Recreational Fishing in the US: Challenges for Management. Fisheries Research, 108(2), 268-276.

Johnston, R. J., Ranson, M. H, Besedin, E. Y., and Helm, E. C. (2006). What Determines Willingness to Pay per Fish? A Meta-Analysis of Recreational Fishing Values. Marine Resource Economics, 21(1), 1-32.

Kaval, P., and Loomis, J. B. (2003). Updated Outdoor Recreation Use Values with Emphasis on National Park Recreation. Retrieved from https://www.researchgate.net/publication/237268913_Updated_Outdoor_Recreation_Use _Values_with_Emphasis_on_National_Park_Recreation

Kearney, M. S., Harris, B. H., Hershbein, B., Boddy, D., Parker, L., and Di Lucido, K. (2014). What's the Catch? Challenges and Opportunities of the U.S. Fishing Industry. Retrieved from http://www.hamiltonproject.org/assets/legacy/files/downloads_and_links/Challenges_opp ortunities_fishing_industry_policybrief.pdf

Kearney, R. E. (2002). Recreational Fishing: Value Is in the Eye of the Beholder. Recreational Fisheries: Ecological, Economic and Social Evaluation. New York, NY: Wiley Press.

Lawrence, K. S. (2005). Assessing the Value of Recreational Sea Angling in South West England. Fisheries Management and Ecology, 12(6), 369-375.

Lew, D. K., and Larson, D. W. (2005). Valuing Recreation and Amenities at San Diego County Beaches. Coastal Management, 33(1), 71-86. 
Lipton, D., Lew, D., Wallmo, K., Wiley, P., and Dvarskas, A. (2014). The Evolution of Non-Market Valuation of U.S. Coastal and Marine Resources. Journal of Ocean and Coastal Economics, 2014(1), 1-25.

Little, J. M., and Berrens, R. P. (2008). The Southwestern Market for Big-Game Hunting Permits and Services: A Hedonic Pricing Analysis. Human Dimensions of Wildlife, 13(3), 143-157.

Livengood, K. R. (1983). Value of Big Game from Markets for Hunting Leases: The Hedonic Approach. Land Economics, 59(3), 287-291.

Loomis, J.B. (2014). Strategies for Overcoming Hypothetical Bias in Stated Preference Surveys. Journal of Agricultural and Resource Economics, 39 (1), 34-46.

Loomis, J. B., Rosenberger, R., \& Shrestha, R. K. (1999). Updated Estimates of Recreation Values for the RPA Program by Assessment Region and Use of MetaAnalysis for Recreation Benefit Transfer. Fort Collins, Colorado: Final Report for the USDA Forest Service.

Lovel, S. J., Steinback, S., Hilger, J. (2013). The Economic Contribution of Marine Angler Expenditures in the United States, 2011. Silver Spring, MD: U.S. Dep.

Commerce, NOAA Tech. Memo.

McConnell, K. E., and Strand. I. E. (1994). The Economic Value of Mid and South Atlantic Sportfishing. Retrieved from https://yosemite.epa.gov/ee/epa/eerm.nsf/vwAN/EE-0036B.pdf

McDowell Group. (2014). Economic Impacts of Guided Hunting in Alaska. Juneau, AK: McDowell Group, Inc. Retrieved from http://www.alaskaprohunter.org/economic_impacts_of_guided_hunting_final.pdf

Minnesota IMPLAN Group. (2009). IMPLAN Professional, version 3.0: User’s Guide, Analysis Guide, Data Guide. Stillwater, MN: Minnesota IMPLAN Group, Inc.

Mozumder, P., Starbuck, C. M., Berrens, R. P., and Alexander, S. (2007). Lease and Fee Hunting on Private Lands in the US: A Review of the Economic and Legal Issues. Human Dimensions of Wildlife, 12(1), 1-14.

National Marine Fisheries Service (NMFS). (2016). Economic Program, Saltwater Angling Valuation Studies. Retrieved from http://www.st.nmfs.noaa.gov/economics/fisheries/recreational/valuation studies/index

National Research Council (NRC). 2006. Review of Recreational Fisheries Survey Methods. Washington, DC: The National Academies Press. 
Navrud, S. (1999). Assessment of Environmental Valuation Reference Inventory (EVRI) and the Expansion of its Coverage to the European Union. Retrieved from http://ec.europa.eu/environment/enveco/others/pdf/evripart1.pdf

Nickerson, N. P., Oschell, C., Rademaker, L., and Dvorak, R. (2007). Montana's Outfitting Industry: Economic Impact and Industry-Client Analysis, (Report No. 212). Missoula, MT: Institute for Tourism and Recreation Research Publications. Retrieved from http://scholarworks.umt.edu/itrr_pubs/212

Outdoor Industry Association, Outdoor Recreation Participation Topline Report (ORPR). (2015). Retrieved from http://www.outdoorfoundation.org/pdf/ResearchParticipation2015Topline.pdf

Phillips, C. (2015, October 6). Email Interview.

Pitts, H. M., Thacher, J. A., Champ, P. A., and Berrens, R. P. (2012). Hedonic Price Analysis of the Outfitter Market for Trout Fishing in the Rocky Mountain West. Human Dimensions of Wildlife, 17(6), 446-462.

Poudel, J. (2014). Economic Impacts of Fishing, Hunting, and Wildlife-Associated Recreation Expenditures Across the U.S. South (Masters' Thesis). Retrieved from http://www.auburn.edu/ jzp0046/pdf/Economic\%20Impact\%20of\%20hunting\%20expen ditures\%20on\%20southern\%20US.pdf

Raguragavan, J., Hailu, A., and Burton, M. (2013). Economic Valuation of Recreational Fishing in Western Australia: Statewide Random Utility Modelling of Fishing Site Choice Behavior. Australian Journal of Agricultural and Resource Economics, 57(4), 539-558.

Randall, A. (1994). A Difficulty with the Travel Cost Method. Land Economics, 70(1), 88-96.

Rhyne, J. D., Munn, I. A., and Hussain, A. (2009). Hedonic Analysis of Auctioned Hunting Leases: A Case Study of Mississippi Sixteenth Section Lands. Human Dimensions of Wildlife, 14(4), 227-239.

Rosen, S. (1974). Hedonic Prices and Implicit Markets: Product Differentiation in Pure Competition. Journal of Political Economy, 82(1), 34-55.

Savolainen , M. A., Fannin, J. M., and Caffey, R. H. (2014). Economic Impacts of the U.S. Gulf of Mexico Recreational For-Hire Fishing Industry. Human Dimensions of Wildlife, 19(1), 72-87.

Smith, V. K. (1989). Taking Stock of Progress with Travel Cost Recreation Demand Methods: Theory and Implementation. Marine Resource Economics, 6(1), 279-310. 
Smith, V. K. (1993). Welfare Effects, Omitted Variables, and the Extent of the Market. Land Economics, 69(2), 12-31.

Steinback, S. (1999). Regional Economic Impact Assessments of Recreational Fisheries: An Application of the IMPLAN Modeling System to Marine Party and Charter Boat Fishing in Maine. North American Journal of Fisheries Management, 19(1), 724-736.

Steinback, S., Gentner, B., and Castle, J. (2004). The Economic Importance of Marine Angler Expenditures in the United States. NOAA Professional Paper NMFS. Retrieved from

https://www.st.nmfs.noaa.gov/Assets/economics/publications/AnglerExpenditureReport/ 2011/pdf/The\%20Economic\%20Contribution\%20of\%20Marine\%20Angler\%20Expendit ures\%20in\%20the\%20United\%20States\%202011.pdf

Taylor, L. O. (2003). The Hedonic Method. The Economics of Non-Market Goods and Resources: A Primer on Non-market Valuation. Berlin, Germany: Springer Publication.

Taylor, J., and Marsh, L. M. (2003). Valuing Characteristics of Transferable Deer Hunting Permits in Kansas. Retrieved from http://www.agmanager.info/events/risk_profit/previous/2003/tMarsh.pdf

Thomas C. W., Hanemann, W. M., Ivar, E., and Strand, Jr. (1986). An Economic Assessment of Marine Recreational Fishing in Southern California. Retrieved from https://swfsc.noaa.gov/publications/tm/swr/noaa-tm-nmfs-swr-015.pdf

Tisdell, C. (2003). Recreational Fishing: Its Expansion, its Economic Value and Aquaculture's Role in Sustaining it. Working Papers on Economics, Ecology and Environment, 93(4), 1-12.

U.S. Fish and Wildlife Service and U.S. Census Bureau (USFWS). (2001). 2001 National Survey of Fishing, Hunting, and Wildlife-Associated Recreation. Retrieved from http://www.census.gov/prod/2002pubs/FHW01.pdf

U.S. Fish and Wildlife Service and U.S. Census Bureau (USFWS). (2006). 2006 National Survey of Fishing, Hunting, and Wildlife-Associated Recreation. Retrieved from https://www.census.gov/prod/2008pubs/fhw06-nat.pdf

U.S. Fish and Wildlife Service and U.S. Census Bureau (USFWS). (2011). 2011 National Survey of Fishing, Hunting, and Wildlife-Associated Recreation. Retrieved from https://www.census.gov/prod/2012pubs/fhw11-nat.pdf

U.S. Fish and Wildlife Service (USFWS), Wildlife and Sport Fish Restoration Program. (2015). Historical Fishing License Data (2004-2015).Retrieved from http://wsfrprograms.fws.gov/Subpages/LicenseInfo/FishingLicCertHistory20042015.pdf 
Walsh, R. G., Johnson, D. M., and McKean, J. R. (1992). Benefit Transfer of Outdoor Recreation Demand Studies: 1968-1988. Water Resources Research, 28(1), 707-713.

Ward, F. A., and Beal, D. (2000). Valuing Nature with Travel Cost Models. Northampton, MA: Edwrd Elgar.

Williams, J.S., and Bettoli, P. W. (2003). Net Value of Trout Fishing Opportunities in Tennessee Tailwaters (Report No. 03-21). Nashville, Tennessee: Tennessee Wildlife Resources Agency. 